\title{
SÔBRE A GENESE DE UMA JAZIDA DE MOLIBDENITA DO RIO GRANDE DO SUL
}

\section{William Georson Rolim de Camargo}

\author{
Í $\mathrm{d}$ i c e
}

I - Introdução

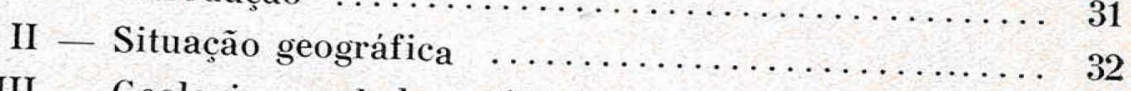

III - Geologia geral da região $\ldots \ldots \ldots \ldots \ldots \ldots \ldots \ldots \ldots . \ldots \ldots$

1. Generalidades $\ldots \ldots \ldots \ldots \ldots \ldots \ldots \ldots \ldots \ldots .34$

2. Descrição petrográfica das rochas $\ldots \ldots \ldots \ldots \ldots \quad 39$

IV - Geologia da jazida $\ldots \ldots \ldots \ldots \ldots \ldots \ldots \ldots \ldots \ldots .48$

1. Estudo dos minerais constituintes do minério e

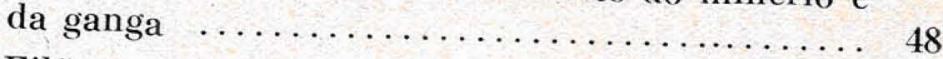

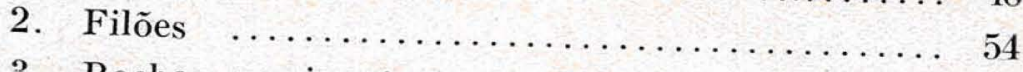

3. Rochas encaixantes $\ldots \ldots \ldots \ldots \ldots \ldots \ldots \ldots . \ldots \ldots$

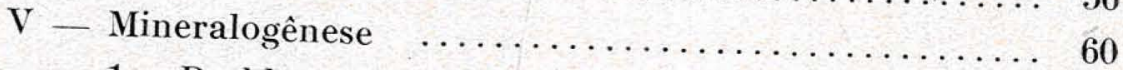

1. Problema da gênese $\ldots \ldots \ldots \ldots \ldots \ldots \ldots \ldots \ldots 61$

2. Classificação do depósito $\ldots \ldots \ldots \ldots \ldots \ldots \ldots .65$

3. Abertura das fendas e formação dos filões .... 66

4. Paragênese dos minerais e sequência de depo-

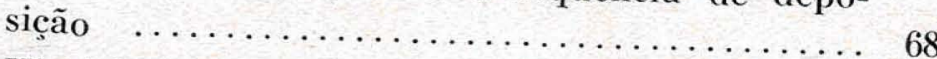

5. Histórico da mineralização $\ldots \ldots \ldots \ldots \ldots \ldots \ldots, 71$

VI - Conclusões

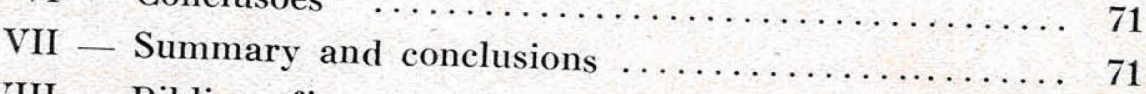

VIII - Bibliografia 


\title{
SÔBRE A GÊNESE DE UMA JAZIDA DE MOLIBDENITA DO RIO GRANDE DO SUL
}

\author{
William Gerson Rolim de Camargo \\ I - Introdução
}

\begin{abstract}
E' necessário salientar a importância e a necessidade do estudo da gênese dos depósitos min'erais, antes de qualquer tentativa de exploração de lavra racional. Èsse estudo prévio da gênese é tão importante e indispensável na prospecção de uma jazida, como a geologia pormenorizada, pois dandỏ à prospecceão um cunho mais racional e científico, facilita e resume sobremaneira os trabalhos da mesma.

Com a finalidade de ser estudada a gênese da jazida de molibdenita de Vacacai e dar alguma contribuição à resolução dêste problema, foi que se elaborou o presente trabalho, após dois anos de pesquisas.

Em uma restrita área do Estado do Rio Grande do Sul, município de São Gabriel, foi verificada a presença de molibdenita, em coexistência paragenética com outros minerais, quase todos sulfètos, formando filões de pequena extensão e possança, mas bem ramificados e intrometidos nas fendas dos xistos da série
Porongos.
\end{abstract}

A prospecção dessa jazida foi iniciada em 1939, pela Diretoria da Produção Min'eral do Rio Grande do Sul, não chegando, entretanto, por motivos vários, a um resultado satisfatório no sentido de ser organizada, na ocasião, a lavra. A molibdenita foi descoberta ocasionalmente, pois a prospecção visava minerais de cobre, visto terem sido encontrados nas proximidades indícios dêstes últimos minerais.

Essa prospecção foi dirigida pelos engenheiros de minas Mariano Sena Sobrinho e J. Pinagel daquela Diretoria. Foram realizadas duas excavações, distantes de $20 \mathrm{~m}$, com o intuito de localizar o minério de cobre e molibdenita. Tais excavações evidenciaram calcopirita e molibdenita, além de outros minerais que serão ainda citados, em filões quartzíferos que seguiam, com pequenas variações, a direção N $45^{\circ} \mathrm{E}$ e a inclinação $60^{\circ} \mathrm{N}$. Com o fito de se verificar o comprimento dêsses filões foi aberta uma trincheira em L, cujos dois ramos faziam $45^{\circ} \mathrm{com}$ a direção dos fi- 
lões. Tais filões mostraram-se estéreis, estando constituidos principalmente de quartzo, pequenos nódulos de calcopirita e ausêucia de molibdenita. Como teremos ocasião de verificar mais adiante, a mineralização do depósito por nós estudado foi de pequena escala.

À vista dos resultados não satisfatórios na época, ou talvez

Em fins de 1942, por sugestão do professor Revnaldo Saldanha da Gama, Diretor do Departamento de Mineralogia e Petrografia e do professor Viktor Leinz, da Diretoria da Produção Mineral no Rio Grande do Sul, teve inicio, por intermédio do autor, nova prospecção da jazida, cuja concessão de pesquisa pertence atualmente a Cia. Brasileira do Cobre. Apesar de ser a jazida considerada presumivelmente de pequena capacidade, tal fato não constituia séria objeção à próspecção no momento, pois que, qualquer quantidade de minério de molibdênio produzida seria útil, dada a escassez dêste material de guerra no Brasil (de conformidade com a classificacão de materiais de guerra, fornecida pelo Govêrno dos Estados Unidos da América do Norte, o molibdênio e seus minérios são considerados materiais "mais escassos", apesar mesmo, dêste país, possuir grandes depósitos de tais minérios (34).

Ocorrências de molibdenita de origens diversas: pegmatítica, hidrotermal e pneumatolítica, têm sido encontrados no Brasil, nos seguintes Estados: Ceará (em pegmatito encaixado em gneis), Espirito Santo, Santa Catarina e Rio Grande do Sul (veios quartziferos), São Paulo e Rio de Janeiro. (33).

No Rio Grande do Sul, a molibdenita tem sido observada não sòmente em Vacacai, mas também em Porto Alegre (lâminas finíssimas no granito), em Lavras (no granito) e em Encruzilhada (em veios quartzíferos de origem hidrotermal) (9).

Outros minerais de molibdênio têm sido observados no Brasil além de molibdenita, principalmente wulfenita, PbMoO4, segundo minério em importância econômica daquele elemento. Assim, no Estado de São Paulo (Itapirapuan) (6) e em Minas Gerais, foram observadas ocorrências dêste mineral, porém de escassa ou nula importância econômica, constituindo mineral secundário em veios de galena argentífera. A wulfenita, que teria sua gênese por alteração, originàriamente contém pequeno teôr de molibdênio em mistura, sob forma ainda não bem conhecida (8).

\section{II - Situação geográfica}

S i t u a çã - A região onde ocorre a molibdenita, objeto de nossos estudos, está situada ao Sul do municipio de São Ga- 
briel, Rio Grande do Sul, no limite com o município de Lavras, nas margens da Sanga Bom Retiro, uma das cabeceiras do Rio Vacacaí e de onde o nome Vacacaí para toda aquela região. Dentro de mais ou menos $2 \mathrm{~km}^{2}$ foram verificadas várias ocorrências de molibdenita, sendo três ao longo daquela sanga. Notam-se que essas ocorrências localizam-se, na totalidade, dentro da zona de contacto do granito, fato êste importante na gênese da jazida, como veremos adiante.

Uma dessas pequenas ocorrências, prospectada recentemente, apresenta-se hoje como pequena jazida. Está ligada por estradas de rodagem à cidade de Lavras e às estações de Ibaré, Von Bock e Suspiro. Tais estações de estrada de ferro distam 'em média 25 $\mathrm{km}$ da jazida, emquanto Lavras dista cerca de $40 \mathrm{~km}$.

Essas estradas de rodagem, infortunadamente, só se apresentam em condições favoráveis no verão; na estação de inverno chegam a ser quase intransitáveis. Entretanto, a exploração de lavra de calcáreo motivou a construção de uma estrada de rodagem de bom estado, entre as pedreiras próximas à jazida de molibdenita e a estação de Ibaré.

Topografia - A topografia da região pode ser classificada entre ondulada e montanhosa, variando os desniveis até o máximo de $100 \mathrm{~m}$. O aspecto fisiográfico é característico dos terrenos geológicos antigos, tendentes a peneplanização, principalmente na parte onde predominam os xistos que sofreram mais a ação da erosão, não só por serem mais antigos que o granito, como também por serem menos resistentes aos agentes erosivos, dada a sua especial constituição mineralógica e estrutural. O relêvo da região dos xistos já atingiu, provàvelmente, quase o seu estágio final de maturidade, mostrando ainda testemunhos de superfícies de erosão mais jovens, como as cristas acentuadas de quartzitos. Dois "hog-backs" típicos são observados na região: o pico Trekont e o conjunto Mantiqueira. Geològicamente, essas duas massas de quartzito, correspondem a uma facies mais acentuada da deposição silicosa do algonquiano.

A erosão na região foi sem dúvida de grandes proporcões, porquanto não foi verificado no teto do batolito granítico, formação ou ilhota de xisto ou rocha de contacto, pelo menos na parte da região estudada. Possivelmente, nos tempos que atravessamos, a erosão já atinge zonas mais profundas do batolito.

E n e r g i a - Os cursos d'água são numerosos mas todos de pequeno volume. Durante a estiagem êste volume diminue sensivelmente. Tratando-se de região pobre em acidentes abruptos, não foram encontradas quedas d'água naturais suscetiveis de serem utilizadas para a obtenção de energia elétrica. Todavia existem desníveis que permitem a construção de barragens artificiais Por outro lado, a reserva de matas é pràticamente nula, pois sa- 
bemos que as matas da "campanha" riograndense são todas ciliares, o que impossibilita qualquer tentativa no sentido de se empregarem locomóveis a lenha para aquele fim. Resta, porém, a possibilidade do uso de carvão mineral que parece existir em grande reserva próximo à estação de Suspiro, de gasogênio, combustíveis derivados do petróleo, ou mesmo lenha, se se lançar mão de florestamentos artificiais (plantações de eucaliptos, etc.).

Mão de obra - Sendo a região rica em ouro aluvionar, há por assim dizer, canalização da mão de obra para a garimpagem e faíscação do ouro quase toda custeada pelos próprios trabalhadores, fato êste, ainda agravado pelo carater despovoado da região. O ouro é encontrado nos depósitos de aluvião, tendo-se originado da desintegração e transporte do material dos filóes quartzo-auríferos, que cortam os xistos em diferentes direções.

O ouro aluvionar apresenta-se em grânulos e pepitas. O garimpeiro retira em média, por processos rudimentares de bateamento, cêrca de $1 / 2$ gr. diária de ouro. Tal fato, sem dúvida, representa concorrência ao trabalho organizado da mineração, vindo portanto encarecer a mão de obra, a qual, não obstante, ainda pode ser considerada de baixo preço.

\section{III - Geologia geral da região}

\section{Generalidades}

A região estudada é constituida litològicamente dos seguintes elementos (ver figs. 1 e 2) :

1. xistos 'epi-mesometamórficos, tipos de transição entre epizona e mesozona, pertencentes à série Porongos de P. F. de Carvalho (7) (algonquiano inferior);

2. granito penetrado nos xistos, formando batolito e de idade algonquiana ;

3. rochas andesiticas de idade mais antiga que o permiano, posterior à série Camaquan.

Na área estudada, da qual interessa principalmente a zona de contacto, onde se passaram os fenômenos de pirometasomatismo e formação dos filões, são predominantes os xistos, representados aqui pelas seguintes rochas: hornblenda-xistos, mica-xistos, cloritaxistos, talco-xistos e em menor importância quartzitos e calcáreo metamórfico (mármore). Entre êstes são predominantes os clorita-xistos, os quais, provàvelmente, ter-se-iam originado da alteração de rochas formadas sob condições de p.t. mais elevado mesozona -, em um fenòmeno de retrometamorfismo. Poderiam, entretanto, os mesmos clorita-xistos, se ter originado de anamor- 
fismo de rochas formadas sob p.t. menos elevado - epizona tais como de talco-xistos e filitos.

Observámos que o calcáreo metamórfico, muitas vezes, se apresenta com impurezas constituidas por silicatos de magnésio e cál-
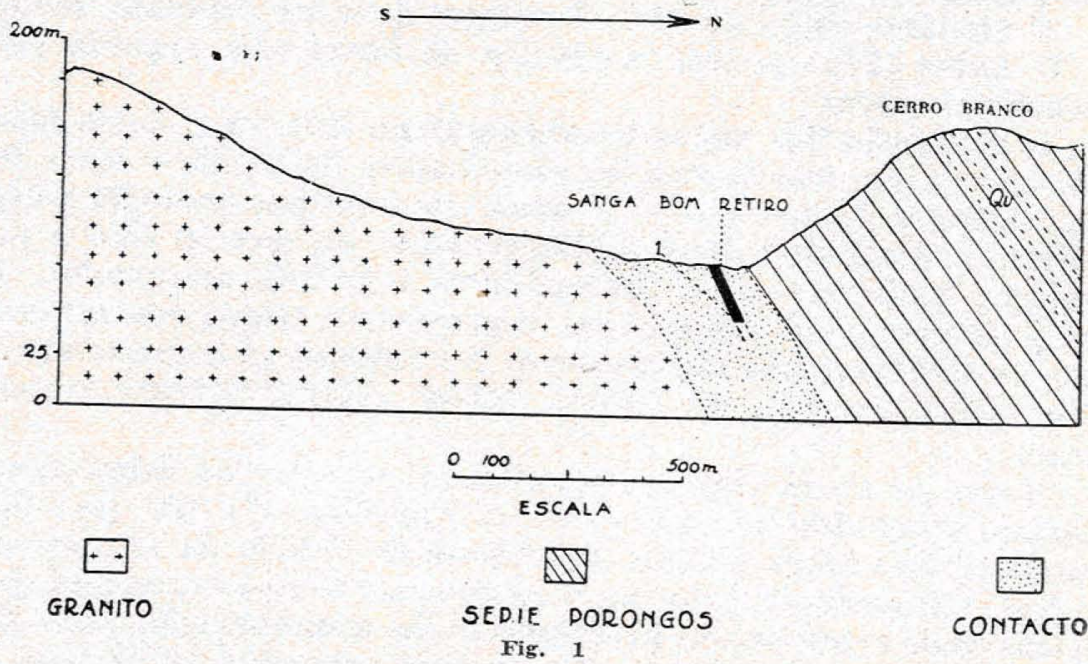

Perfil geológico esquemático da região da jazida, notando-se o batolito granítico, a zona de contato, na qual se encaixa o filão mineralizado, e os xistos da série Porongas.

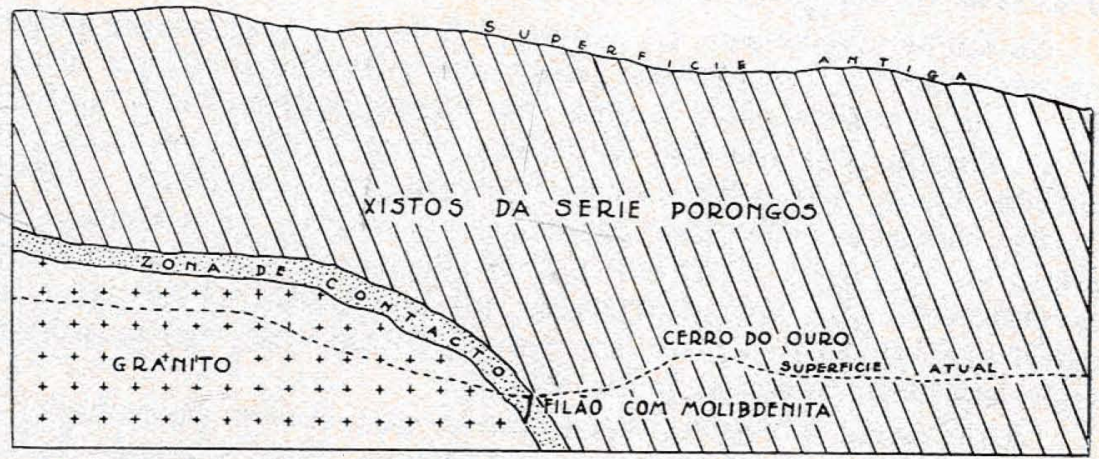

Fig. 2

Esquema mostrando a superfíeie antiga e a superfície atual da região, após a erosão.

cio (ver fig. 3 e análise química pg. 43), o que nos leva a admitir que sofreu um processo de metamorfismo suficientemente intenso, para formar silicatos. Acresce ainda, o fato de ter sido encontrada a titanita nos xistos da série Porongos, e sendo tal mineral um dos primeiros da série cristaloblástica (grande fôrça de cristalização), segundo Grübenmann-Niggli (2), é de se supor que os xistos ricos em titanita se tenham formado sob condições de 
p.t. elevado e que atualmente estejam sofrendo, ou processo de retrometamorfismo ou de intemperismo. Portanto, a série Porongos parece ter sofrido metamorfismo de mesozona e após regressão, para se apresentar tal como hoje, epimesometamorfizada.

O metamorfismo da série Porongos deve ter ocorrido, segundo V. Leinz (24), na fase orogênica do huroniano, seguida pela intrusão granítica.

A colocação dos xislos no algonquiano inferior e a sua identificação com outras formações semelhantes do Brasil - série Minas, série São Roque, etc. - só pode ser feita por analogia petrográfica, por serem rochas litològicamente do mesmo tipo e por analogia geológica, pelos dobramentos tetònicos acentuados. E' provável que todas essas séries representem tratos contemporân'eos da sedimentação algonquiana. No entanto, só o acréscimo de observações poderão, no futuro, solver definitivamente o problema.

Tanto os xistos como os granitos se agregam ao denominado "escudo riograndense", de P. F. de Carvalho (7) (29, pg. 150), complexo de rochas antigas do Sudeste do Estado do Rio Grande do Sul. Êsse complexo forma o embasamento das formaçóes geológicas mais recentes. As principais áreas mineralizadas nesse Estado localizam-se nas formaçóes antigas, tais como as jazidas de cassiterita e wolframita de Ëncruzilhada (15), (9), cobre e ouro de Lavras e Caçapava (23), (25).

Os xistos observados na região de Vacacaí, apresentam pequenas variações na direção dos planos de xistosidade, o que aliás é fato comum nesse tipo de rocha. Em limite de observação de $3 \mathrm{~km}$ foi verificada uma direção N $10^{\circ} \mathrm{E}$ e outra $\mathrm{N} 90^{\circ} \mathrm{E}$; a inclinação também varia, pois foram observadas inclinações de $45^{\circ}$ a $60^{\circ} \mathrm{E}$.

Os esforços tectònicos ocorridos na região provocaram nos xistos, rochas mais flexíveis, apenas dobramentos e enrugamentos enquanto que nos quartzitos, falhas. Assim, observámos na região uma falha de quartzito, provàvelmente não acompanhada, senão em dobramentos, pelos xistos.

Observando a região, verificámos que existe alternância de xistos, quartzitos e calcáreos metamórficos. Essa alternância parece indicar facies originária marinha ou lagunar, posteriormente atuadas pelo dinamometamorfismo e trabalhadas pela gliptogênese, até a denudação do batolito granítico, o qual exibe numerosos afloramentos próximos à jazida (batolito de Lavras).

A intrusão granítica, responsável pela formação do grande batolíto, foi posterior à formacão dos xistos, a julgar-se pelos indícios no contacto, de metamorfismo térmico e de injeção "lit-parlit". Esse metamorfismo fez resultar na zona de contacto, xistos feldspatizados e migmatitos que se assemelham a gneis. São diferenciados dêstes apenas pela situação geológica, sendo indistintos 
petrogràficamente. Explica-se a pequena influência que teve a intrusão granítica nos xistos, pela grande estabilidade dos minerais destas rochas metamórficas, formadas em condições de p.t.médio (mesozona).

Além da injeção "lit-par-lit" e formação de xistos feldspatizados, a intrusão granítica por sua ação metamórfica provocou a formação de epídoto na zona de contacto. Assim, observam-se principalmente na parte mais próxima ao batolito, núcleos de epidoto dentro do granito, ou então, núcleos de xistos não totalmente epidotizados. Notam-se no centro de tais núcleos, zonas mais escuras constituidas de hornblenda.

$O$ batolito granítico deve ter se constituido a grande profundidade porquanto o granito é de média granulação passando a grosseira, o que mostra formação sob resfriamento lento, dando tempo a um maior desenvolvimento dos germens cristalinos. Além

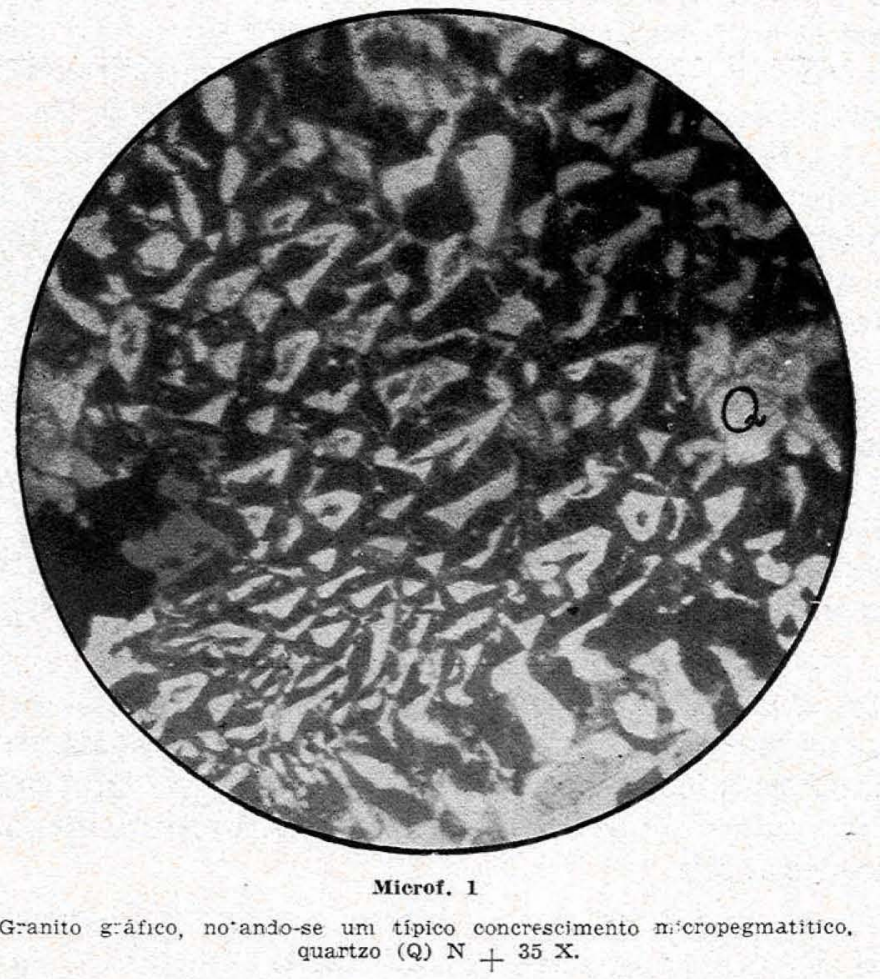

dêste fato, o batolito apresenta outros característicos de intrusão profunda, tais como: existência de veios formados sob p.t. elevado, concrescimentos micropertíticos e micropegmatíticos, presença de biotita e ausência de piroxênio sódico, textura miarolítica e falta de larga albitização (40) (figs. 2 e 5 e microfotos 1 e 4). 
Não só granito e xistos foram observados na região, como também afloramentos de andesito, de formação posterior. A idade posterior é comprovada pela posição geológica do andesito que se superpõe ao granito e aos xistos. Confirmando êste último fato, foram encontrados no interior do andesito, núcleos de granito não totalmente digeridos.

O vulcanismo andesítico foi posterior também à formação da série Camaquan, presumivelmente devoniana (V. Leinz, 24). Superpondo-se ao andesito foram verificadas ocorrências de blocos esparsos de arenito arcosiano friável ferruginoso e folhelho argiloso, o que possivelmente são relíquias da série Camaquan, a qual teria sido primeiramente atravessada e fraturada pelo vulcanismo andesítico e, posteriormente erodida, deixando apenas alguns vestígios de sua existência. O limite superior do andesito não poude ser determinado na região por falta de dados geológicos. Considerando-se entretanto a sua semelhança petrográfica com outras formações andesíticas do Estado, como Seival, Bom Jardim e Cerro dos Martins, localizadas próximas, principalmente a primeira, podemos considerar o andesito de Vacacaí como sendo da mesma idade dessas demais formações. Segundo V. Leinz, o vulcanismo andesítico se deu entre o periodo de formação da série Camaquan e o permo-carbonifero, sendo essas manifestações vulcânicas responsáveis por numerosas mineralizações de ouro e cobre que se observam no Rio Grande do Sul (23) (24) (25). Assim, as jazidas de cobre de Camaquan, Seival e as jazidas de ouro de Lavras formaram-se por soluções provenientes do magma andesítico. No capítulo referente à mineralogènese, discutiremos as duas possibilidades de formação da jazida de molibdenita de Vacacai, ou seja, a partir de soluções andesíticas ou de soluçṍes graníticas.

Xistos e granitos são cortados por numerosos filões quartziferos, que seguem, na maioria das vezes, a direção de xistosidade dos termos metamórficos. Ėsses filões são, ora mineralizados e então apresentam molibdenita, calcopirita, bornita, etc., ora completamente estéreis.

Além do granito e xistos, foram observadas ocorrências de folhelhos betuminosos, cuja existência, segundo P. F. de Carvatho (7), se explica como remanescentes do grupo Irati, permiano, conservados livres da erosão por uma falha de terreno antigo, cuja escarpa de falha se exibe no granito porfiróide, com a direção EW. 


\section{Coluna geológica na área de Vacacaí}

\begin{tabular}{|c|c|}
\hline \multirow[t]{2}{*}{ Permo-carbonifero } & $\begin{array}{l}\text { - Folhelhos betuminosos do grupo Irati } \\
\text { (segundo P. F. de Carvalho). } \\
\text { - Carvão - não observado na região, } \\
\text { aflora em Suspiro a } 25 \mathrm{~km} \text {. }\end{array}$ \\
\hline & - Discordância \\
\hline \multirow[t]{2}{*}{ Devoniano? } & $\begin{array}{l}\text { - Série Camaquan. Arenitos arcosianos e } \\
\text { folhelhos argilosos cerâmicos fratura- } \\
\text { dos e rolados. }\end{array}$ \\
\hline & -- Discordância \\
\hline Siluriano & - (não observado) \\
\hline \multirow[t]{2}{*}{ Cambriano $_{0}$} & - (não observado) \\
\hline & — Discordância \\
\hline \multirow[t]{2}{*}{ Algonquiano } & $\begin{array}{l}\text { - Intrusão granitica - Granitos alcali- } \\
\text { nos com filões quartziferos. Pórfiros } \\
\text { graniticos. } \\
\text { - Série Porongos - filitos, talco-xistos, } \\
\text { clorita-xistos, mica-xistos, hornblenda- } \\
\text { xistos, quartzitos e calcáreos metamór- } \\
\text { ficos. }\end{array}$ \\
\hline & - Niscordäncia \\
\hline Arqueano & - (não observado) \\
\hline
\end{tabular}

2. Descrição petrográfica das rochas.

$\mathrm{X}$ is to s - Como já tivemos ocasião de ver, êstes xistos compreendem as seguintes rochas: hornblenda-xistos, mica-xistos, mica-clorita-xistos, clorita-xistos, talco-xistos, filitos, quartzitos, e calcáreos metamórficos, os quais serão descritos sumàriamente, abaixo.

Hornble nda- $\mathrm{x}$ is to s - Estas rochas são escassamente representadas, pois a maior parte está retrometamorfizada, seja em clorita-xistos, seja em serpentinitos. Possuem em geral granulação fina, mas podem apresentar também granulação grosseira devido a recristalização em conseqüência de ação térmica de contacto, provocada pela intrusão granítica. Muitas partes desta ro- 
cha apresentam-se semi-alteradas, formando hornblenda-cloritaxistos.

Os constituintes mineralógicos desta rocha são os seguintes: hornblenda, clorita, scricita, quartzo (em pequena quantidade), titanita, (com halo claro de carbonato) e apatita. A hornblenda se apresenta em cristais distintos, mais desenvolvidos, sem contudo formar porfiroblastos. A estrutura é xistosa e a textura granuloblástica ou xenoblástica.

O anfibolito (microfoto 2), transformação metamórfica do hornblenda-xisto e como tal pode ser considerado como hornblenda-cornubianito, é rocha macroscòpicamente melanocrática, de estrutura granular média. Os constituintes mineralógicos do anfibolito são mais ou menos os mesmos do hornblenda-xistos:

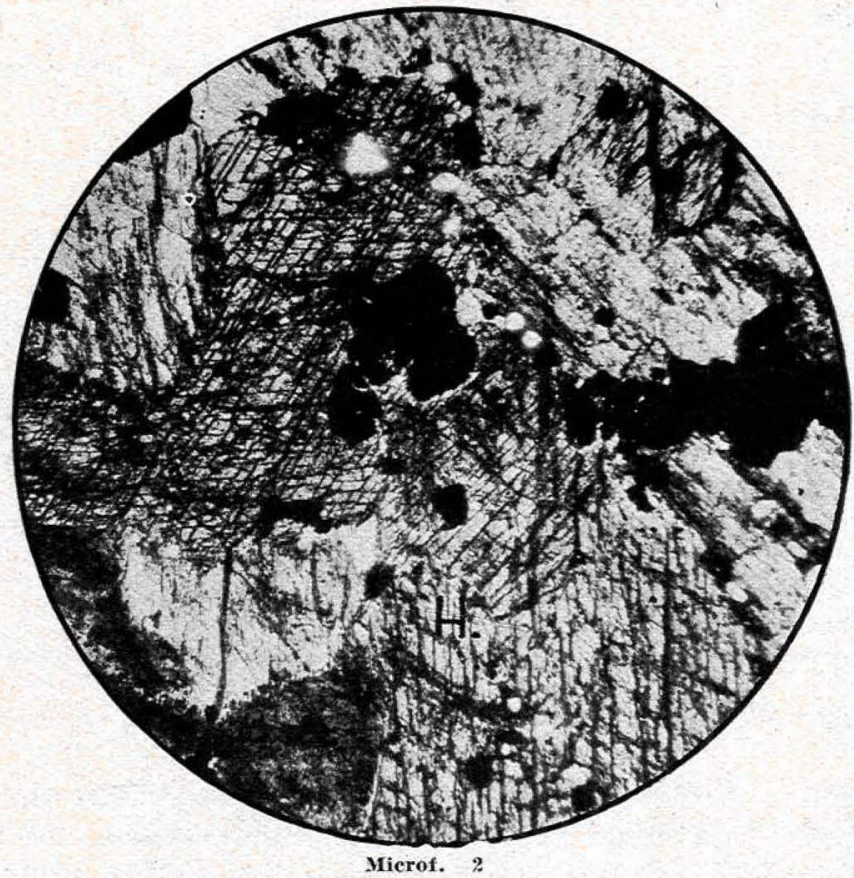

Anfibolito, notando-se hornblenda (H), às vezes alterada em clorita. 0 mineral opaco é calcopirita. L.N. $35 \mathrm{X}$.

hornblenda, clorita como produto de alteracão da hornblenda, epídoto formando núcleos e vênulas secundárias, titanita com halo transparente e muscovita parcialmente cloritizada.

M i c a - x i s t o s - Estas rochas são ainda mais escassas que as anteriormente descritas. Quase sempre exibem muita clorita, representando assim tipos intermediários de mica-clorita- 
xistos. A estrutura é xenoblástica. Composição mineralógica: muscovita, clorita e quartzo.

C 1 o r i t a - x i s t o s - Constituem a maior parte das rochas metamórficas da região estudada. São de côr verde escura, brilho sedoso e planos de xistosidade evidentes. Macroscòpicamente, são diferenciados dos talco-xistos, por serem os cloritaxistos, em geral, de tonalidade verde mais escura. Microscòpicamente, a rocha é constituida principalmente de clorita e quartzo. Èste min'eral é ora primário (singenético - originário da rocha) e ora secundário (epigenético - originário das soluções residuárias). O quartzo secundário só é encontrado, quando o cloritaxisto constitue a rocha encaixante.

A estrutura dos clorita-xistos é nitidamente xistosa, dada a orientação da clorita e do quartzo primário. Textura granuloblástica.

$\mathrm{T}$ a $\mathrm{l}$ c o - x i s t o s - Apresentam-se de côr verde, planos de xistosidade nítidos, de brilho sedoso. São mais freqüentes que os hornblenda-xistos. Talco-xistos são encontrados comumente nas fraturas e falhas dos xistos, onde houve maior infiltração de águas superficiais. Microscòpicamente, são fàcilmente confundidos com os sericita-xistos, dada a semelhança do talco com a sericita, òticamente, e também à dificuldade de se distinguir um do outro pela dimensão exígua dos cristais, não permitindo, dêste modo, observações muito perf'eitas. Nota-se, às vezes, estrutura "microplissée".

Q u a r t z i t o s - Os quartzitos cobrem pequena extensão da região estudada, mas em compensação se apresentam em formações muito desenvolvidas 'em uma direção apenas. Sendo rochas muito resistentes à ação dos agentes erosivos, aparecem nitidamente no terreno, destacando-se das demais formações, constituindo salientes morfológicos bem acentuados (conjunto Mantiqueira e pico Trekont). Formam lente estrato bem longa (cerca de $10 \mathrm{~km}$ ), com uma dobra ou falha, como foi esquematizada no mapa anexo. Os quartzitos são distintos dos filões quartzíferos pela sua massa relativamente considerável, por serem concordantes como os xistos e por serem desprovidos de salbandas.

C a l cá r e o m e t a mó r f i co-O calcáreo é formado por lentes intercaladas nos xistos, em concordância com os mesmos (mapa anexo), que seguem a crista de quartzito, até mesmo na sua falha. As lentes se sucedem como as contas de um rosário, apresentando dimensões variáveis em comprimento e espessura. (As maiores lentes possuem $300 \mathrm{~m}$ de comp. e 20-30 $\mathrm{m}$ de largura).

O calcáreo apresenta granulação variável; fina, com aspecto compacto, até grosseira com aspecto sacaroide (fig. 3). Quase sempre puro, sem inclusões, perfeitamente branco (tipo Carrara) 
ou com tonalidades claras de azul, rosa ou cinza. O calcáreo, pela sua relativa abundância já foi prospectado várias vezes para indústria de cimento. Entretanto, até o presente, os resultados foram negativos, seja pela pequena capacidade das jazidas (cêrca

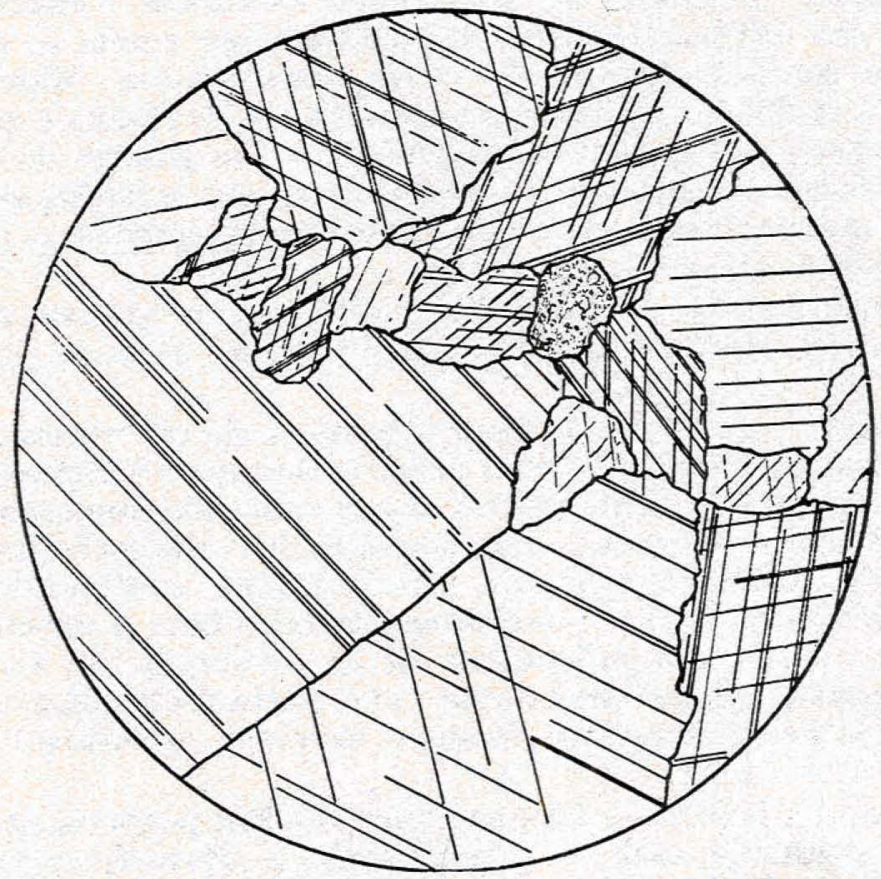

Fig. 3

Secção delgada do calcáreo, notando-se calcita (com traços de clivagem) e um núcleo de silicato.

de 1.500 .000 de ton.), seja ainda pela explorabilidade pouco econômica. A composição química é satisfatória, pois é calcáreo sem impureza e com teôr baixo em $\mathrm{MgCO}_{3}$. O teòr máximo observado em $\mathrm{MgCO}_{3}$, foi de $33,9 \%$ e o mínimo de $0,7 \%$ (26). E' bom notar que aquela porcentagem elevada de $33,9 \%$ foi observada apenas em uma jazida de pequena capacidade, o que de modo algum invalida ou influe nos resultados gerais. Os teôres das maiores jazidas oscilam entre $0,7 \%$ e $6,9 \%$, sendo bem satisfatórios para fins de industrialização. O calcáreo mostra, algumas vezes, xistosidade nítida a olho nú, pela alternância das faixas escuras e claras.

Quìmicamente pobre em $\mathrm{MgO}$, èste calcáreo é recomendável para a fabricação de cimento. Atualmente é explorado para a fabricação de cal hidráulica. 
Análise química do calcáreo de Vacacaí

\begin{tabular}{|c|c|}
\hline Perda ao fogo (I & $44,76 \%$ \\
\hline Sílica $\left(\mathrm{SiO}_{2}\right) \quad \ldots$ & 0,06 \\
\hline Alumina $\left(\mathrm{Al}_{2} \mathrm{O}_{3}\right)$ & 0,35 \\
\hline $\mathrm{Cal}(\mathrm{CaO}) \quad \ldots .$. & 50,87 \\
\hline Magnésia (MgO) & 4,24 \\
\hline
\end{tabular}

Analista: Laboratório Central da Produção Mineral.

G r a n i t o - O granito é róseo, de granulação média, apresentando ortoclásio, quartzo e biotita. Apresenta-se, como as rochas ácidas em geral, sob a forma de batolito, como admitimos nas figs. 1 e 2 e mapa anexo. A erosão, denudando a região fez aflorar o granito em numerosos pontos e por isto, a região granítica é notada especialmente pela sua riqueza de afloramentos. O granito se apresenta pouco alterado. Cobrem-no na parte mais superficial, formações eluvionais de areia. Apresenta disjunção em almofadas.

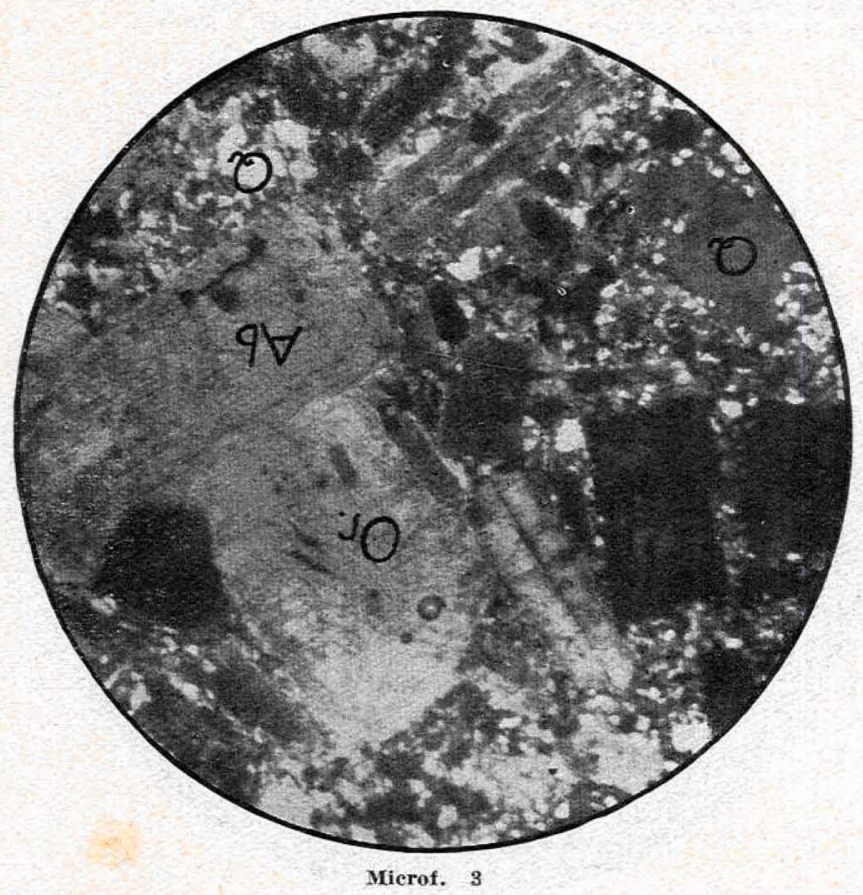

Pórfiro granítico, mostrando quartzo (Q), raramente em fenocristais, ortoclásio (Or), albita (Ab), ambos frequentes como fenocristais e blotita como acessôrio. $\mathrm{N}+35 \mathrm{X}$. 


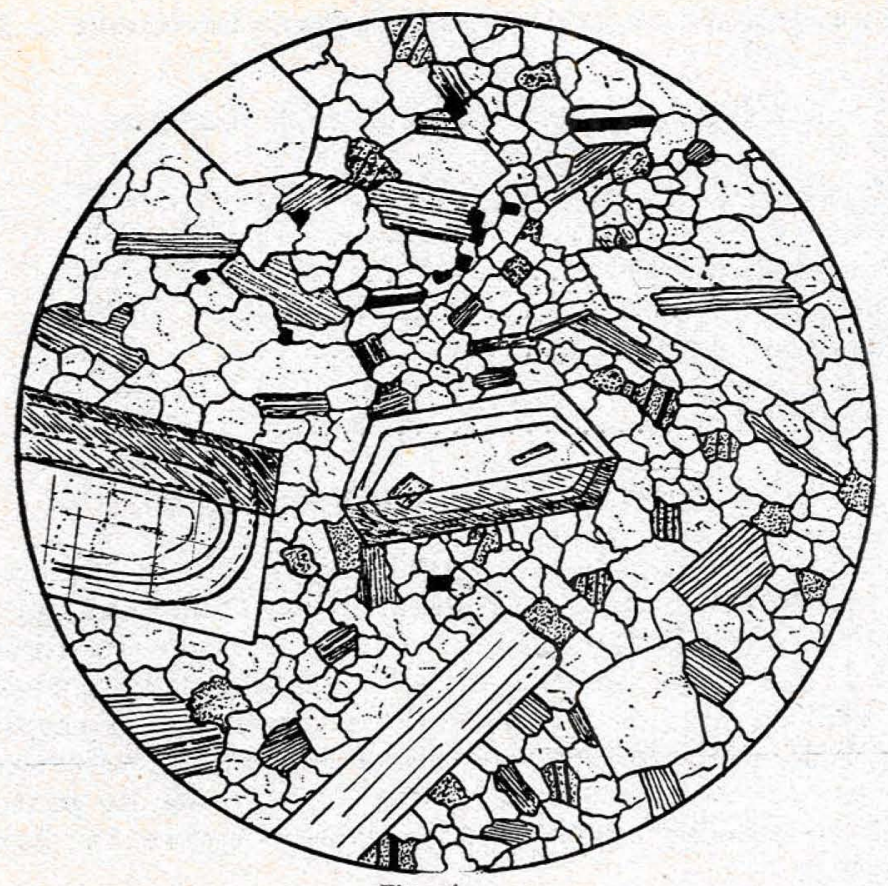

Fig. 4

Seccão delgada de pórfiro granítico, notando-se plagioclásio zonado em fencoristais, quartzn (com inclusōes puntiformes) e mica.

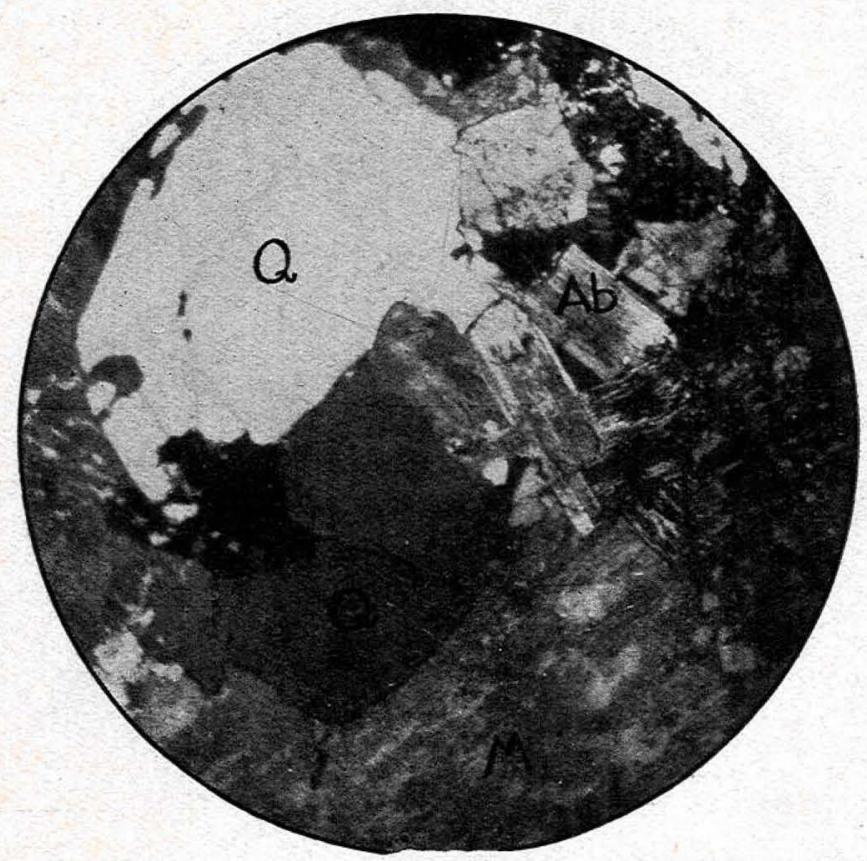

Mierof. 4

Granito, mostrando quartzo (Q), plagioclásio albita (Ab) e ccncresciGranito, mostrando quartzo (Q), plagioolasio $\mathrm{N}+35 \mathrm{X}$. 
Em alguns pontos foram notados diques de pórfiro granítico (microfoto 3 e fig. 4 ).

Microscòpicamente, é a seguinte a composição mineralógica do granito: quartzo, ortoclásio, albita-oligoclásio, microclínio, mi-

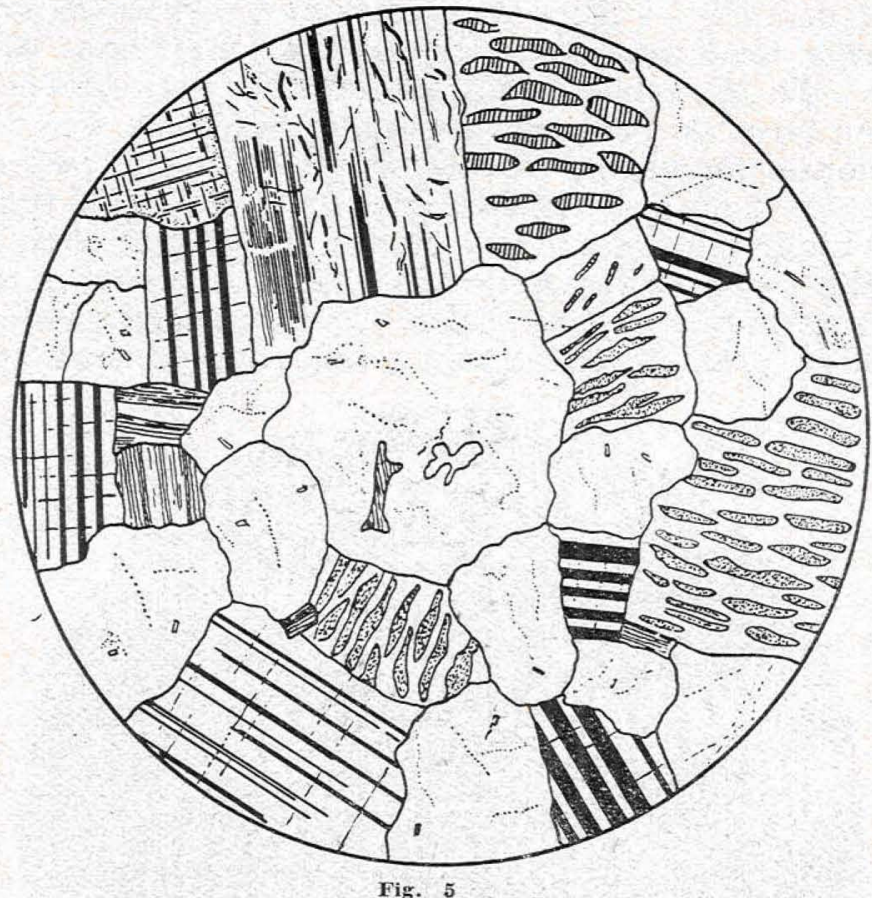

Secção delgada de granito, notando-se quartzo, ortoclásio, concrescimentos micropegmatíticos e micropertíticos, plagioclásio e biotita.

cropertito e micropegmatito, como componentes essenciais, e biotita em pequena poreentagem como constituinte acessório (microfoto 4 e fig. 5). Dada a porcentagem quase insignificante de elementos máficos, esta rocha pode ser classificada de acôrdo com Johannsen como alasquito (18).

Quartzo - Apresenta-se em cristais alotriomorfos, com inclusões de biotita, plagioclásio ou ortoclásio, além de inclusões líquidas e gasosas em número elevado. Apresenta-se freqüentemente em concrescimento com ortoclásio, formando micropegmatitos.

Ortoclásio - E' raramente encontrado em cristais não concrescidos e está freqüentemente associado ao quartzo ou à albita, formando respectivamente, micropegmatitos e micropertitos. Apresenta-se parcialmente sericitizado.

Plagioclásio - Èste mineral foi encontrado em concrescimento com o quartzo ou em cristais não concrescidos. Em quantidade secundária em relação aos ontros cemponentes essenciais. 
Biotita - E' mineral essencialmente escasso. Apresenta-se em cristais idiomorfos e parcialmente muscovitizados.

Fluorita foi verificada em algumas amostras de granito. Acha-se, entretanto, em quantidade subordinada.

A n d e s i t o - Macroscòpicamente é rocha compacta, bem dura e com tendência melanocrática na tonalidade. Notam-se, mesmo a olho nú, feno-cristais de anfibólio com dimensões que variam em torno de $1 \mathrm{~mm}$ na sua maior dimensão. Tais fenocristais tornam-se fàcilmente visiveis quando a rocha está em vias de alteração, dada a alteração mais rápida do feltro fundamental. $O$ andesito, formado pela efusão de magma mais recente que granito e que as formações da série Camaquan, mostra freqüentemente núcleos destas rochas. Assim, notamos no andesito, inclusões de granito epidotizado e na zona de contacto com o

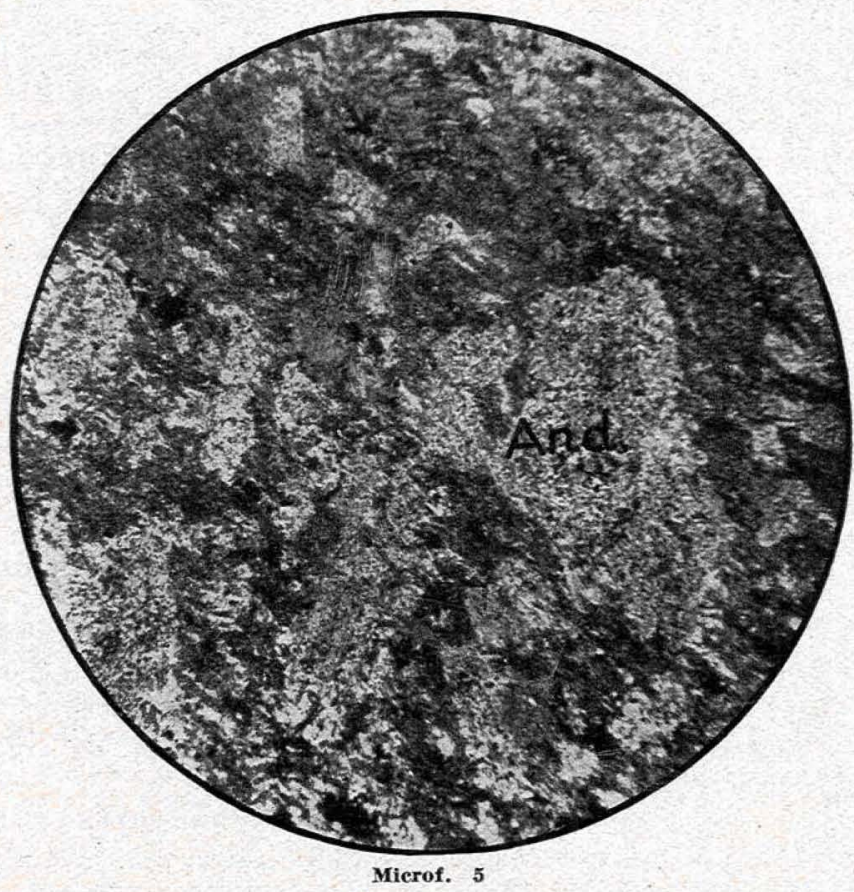

Andesito, notando-se fenocristais de andesina (And) com intensa disseminação de pirita (pontos pretos). O feltro está constituido por micrólitos de hornblenda comum principalmente. L.N. $35 \mathrm{X}$.

granito, um tipo de andesito misturado com material siálico, emprestando-lhe aspecto mais leucocrático. Ao microscópio, nota-se maior riqueza de plagioclásio albita neste tipo misturado de rocha.

Microscòpicamente, (microfoto 5 e fig. 6) a textura é holocristalina e porfiritica. A estrutura tende à traquítica, por inci- 
piente iso-orientação dos micrólitos. Os fenocristais são de hornblenda comum $\left(Z / \mathrm{c}=17^{\circ}\right)$ e de plagioclásio andesina (30 a $40 \% \mathrm{An})$.

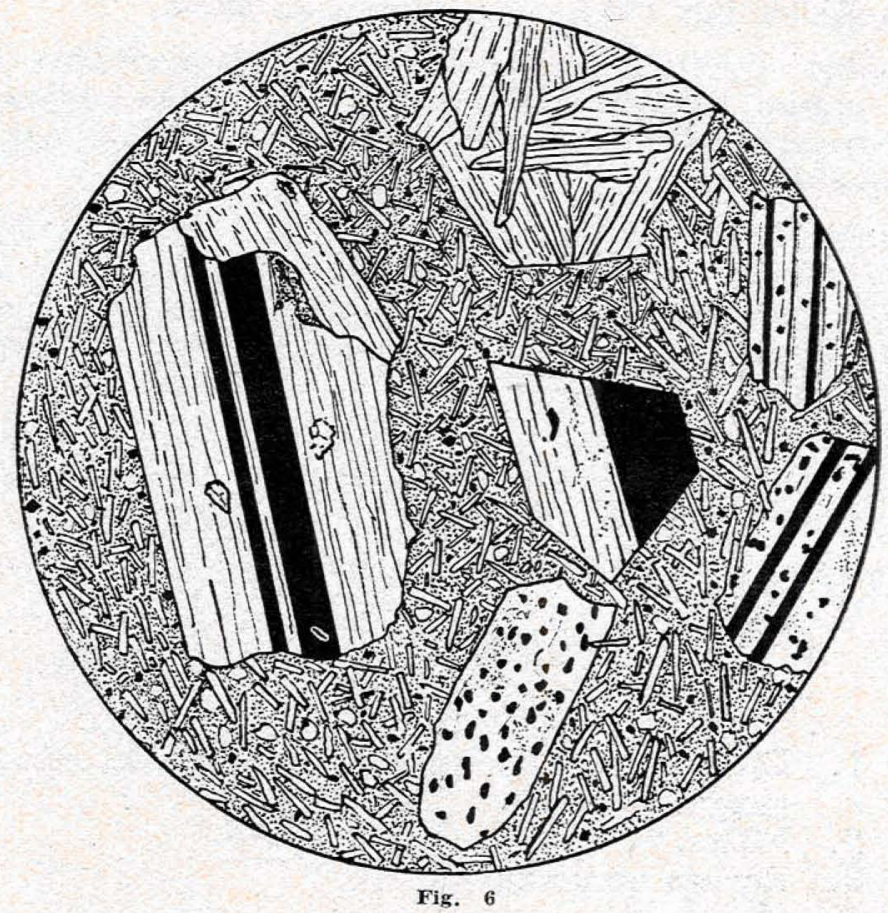

Seç̧ão delgada de andesito, notando-se fenocristais de hornblenda (traços de clivagem paralelos) e de andesina (com disseminaçōes pretas de pirita) e feltro de hornblenda (cristais prismáticos), quartzo e pirita.

A hornblenda forma cristais idiomorfos bem nítidos, individuais ou geminados segundo (001) de dois individuos ou ainda, geminados polissintéticos. Em geral, êste geminado de mais de dois individuos apresenta duas lamelas finas entre duas outras mais espessas, o que aliás é fato bastante comum nos anfibólios. O pleocroísmo não é muito acentuado em secção microscópica: $\mathrm{X}$ - amarelo claro, $\mathrm{Y}$ - verde azulado, Z - pardo amarelado.

Muitas vezes os fenocristais de hornblenda se apresentam fraturados, continuando os fragmentos a ocupar o local do antigo fenocristal. Com referência a êsse fato somos levados a classificar a estrutura como apresentando tendência glomeroporfírica. Verifica-se a m’esma tendência dos plagioclásios para formarem agrupamentos semelhantes a glomérulos. 
O plagioclásio andesina apresenta-se em fenocristais, porém menores e mais numerosos que os de hornblenda. Os contornos não são nítidos /mas a tendência é idiomórfica. Os cristais individuais são raros, sendo mais freqüentes os geminados segundo a lei da albita. São ricos em inclusões de pirita.

O feltro está composto na maior parte de micrólitos de hornblenda comum, a qual forma cristais prismáticos idiomorfos e alongados segundo Z. Cristais de pirita e de feldspato existem em menor quantidade.

0 andesito apresenta ainda cristais de quartzo de origem secundária, não magmática, formados provàvelmente por assimilacão, pois forma núcleos não digeridos no seio da rocha andesítica. Êstes cristais de quartzo possuem tendència idiomórfica e não apresentam inclusões.

Além dêstes constituintes, notamos no andesito minerais secundários como epídoto e carbonatos, provenientes da alteração de minerais primários.

Esta rocha se enquadra como um hornblenda-andesito.

\section{IV - Geologia da jazida}

1. Estudo dos minerais constituintes do minério e da ganga.

2. Filões.

3. Rochas encaixantes.

1. Estudo dos minerais constituintes do minério e da ganga.

Os minerais que ocorrem na jazida de Vacacaí são os seguintes : molibdenita, calcopirita, magnetita, pirita, ouro elementar, cobre elementar, fluorita, epidoto, calcita, limonita, bornita, e quartzo, minerais êstes que passaremos a descrever.

$\mathrm{M}$ o $\mathrm{l}$ i b d e $\mathrm{n}$ i $\mathrm{ta}$ - Apresenta-se ora interclusa entre os cristais de quartzo dos filóes, ora intercrescida com calcopirita e associada à magnetita, formando filões e, às vezes, preenchendó fendas do xisto encaixante. Dêste modo, notamos três variedades de minério, que são as seguintes: minério quartzifero - branco com manchas de molibdenita; minério cuprífero - amarelo com manchas de molibdenita e minério xistoso - de côr escura, quase negra, com manchas cinzentas e brilhantes de molibdenita.

$\mathrm{O}$ minério quartzífero, microscòpicamente, apresenta o aspecto exibido pelo microfoto 6 : lâminas de molibdenita entre grãos de quartzo geralmente localizadas na periferia do filão. 


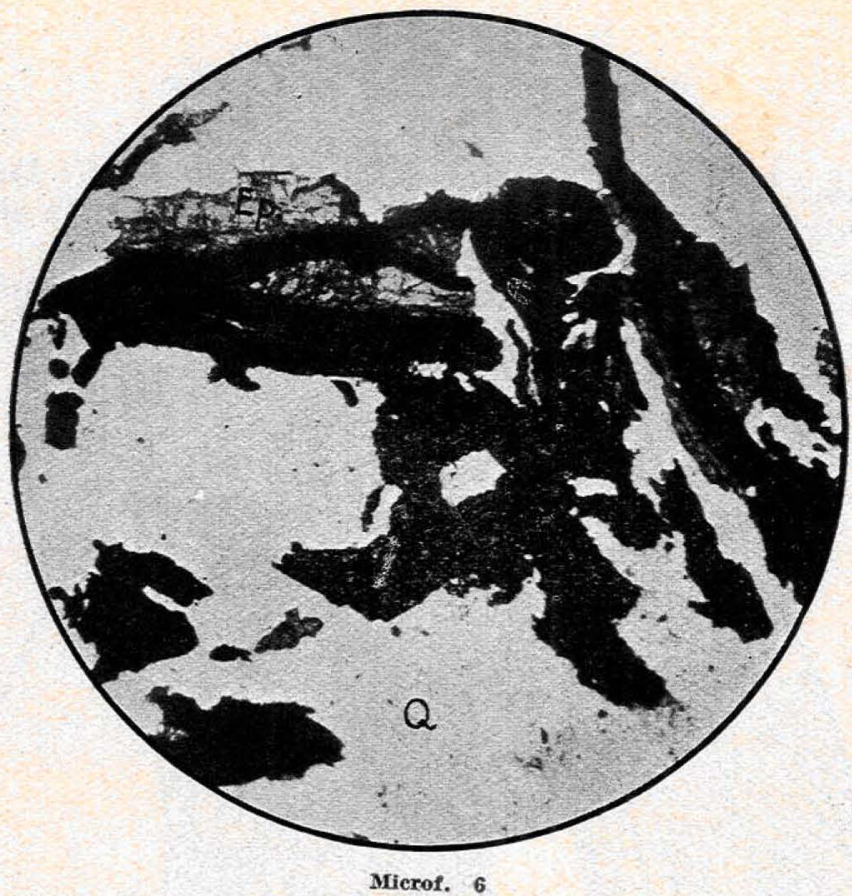

Mierofotografia de uma zona do filão D, mostrando a acrociação entre epidoto (Ep), mol bdenita (cpaca) e quartzo (Q). L. N. $35 \mathrm{X}$.

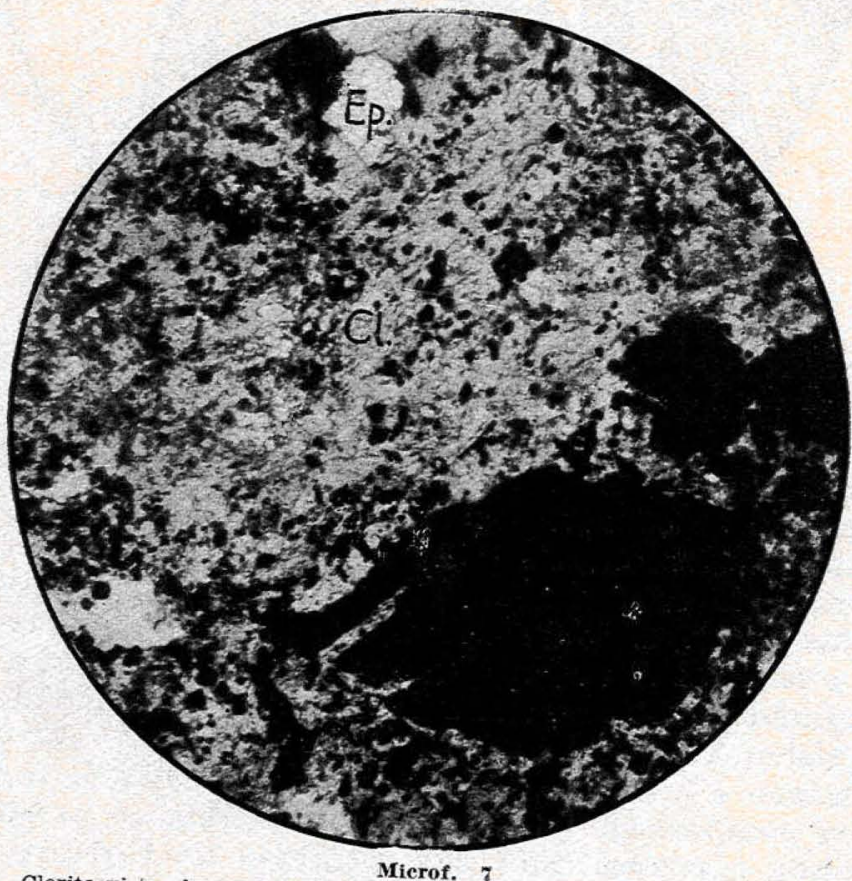

Clorita-xisto das circunvizinhanças de $20 \mathrm{~cm}$ do filão C, notando-se nério aproveitável. Ep- epídoto. Cl- Clorita L.N. $35 \mathrm{X}$. 
0 minério cuprifero mostra o aspecto da fig. 7: lâminas de molibdenita acham-se intercrescidas com a calcopirita circundando também cristais dêste último mineral.

O minério xistoso apresenta-se constituido de lâminas de molibdenita interpenetradas nos xistos, de modo concordante com a xistosidade (microfoto 7 e fig. 8 ).

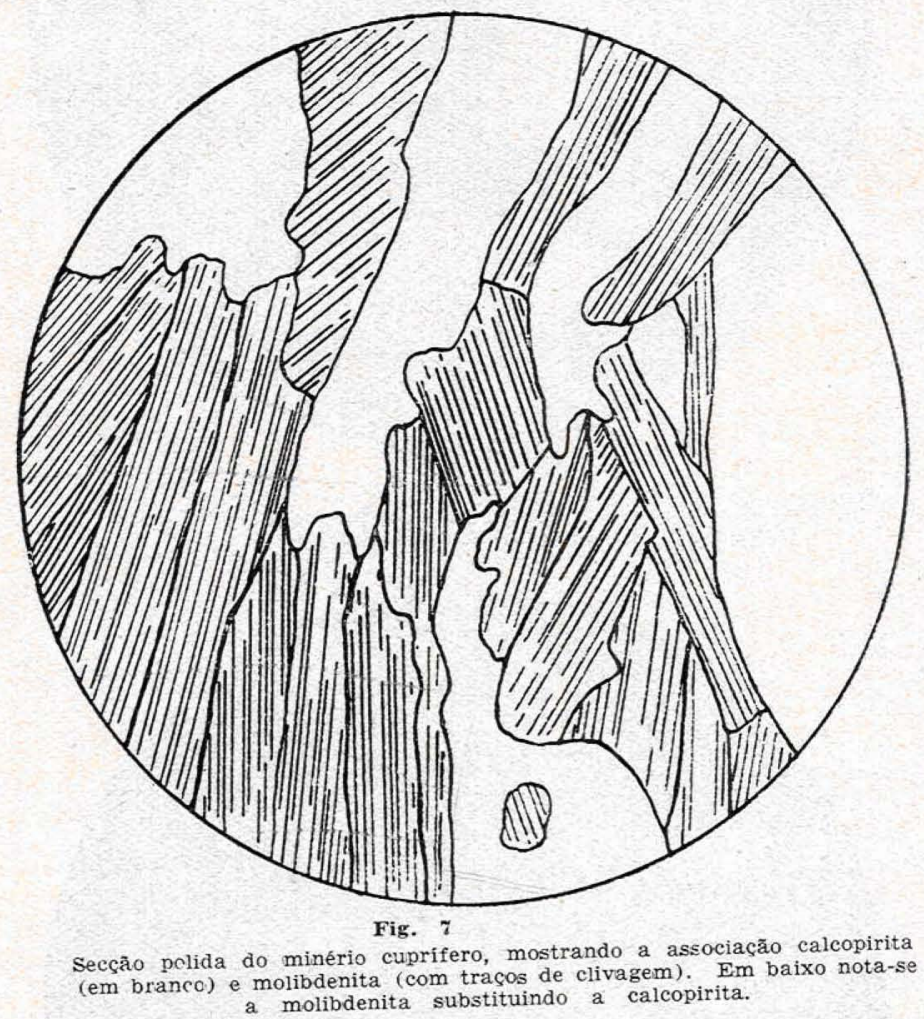

A molibdenita, em todos os tipos de minério descritos, apresenta-se sempre com hábito lamelar. Como sòe acontecer, não foram observados cristais perfeitos dêste mineral.

A exemplo de quase todos os sulfêtos e ainda mais, pela sua particular propriedade de fácil clivagem (clivagem basal segunda (0001), a molibdenita se desfaz com extrema facilidade, principalmente quando a rocha encaixante está alterada e não oferece substrato resistente, o que é o caso do minério xistoso. Por possuir hábito micáceo e grafitoso, fácil clivagem, resistência à oxidação e pela sua composição química, a molibdenita se presta para ser beneficiada e concentrada pelo processo da flutuação. As partículas de molibdenita flutuam com facilidade em quase todos os reagentes de flutuação, podendo-se obter com êste processo, con- 
centrados de $90 \%$ ou mais de $\mathrm{MoS}_{2}$. A maior dificuldade do beneficiamento do minério, para concentrar molibdenita, está no fato dêle conter calcopirita. A separação dêste mineral da molibdenita não é resolvida com uma operação exclusiva de concentração. E' necessária a flutuação seletiva; usamos duas baterias

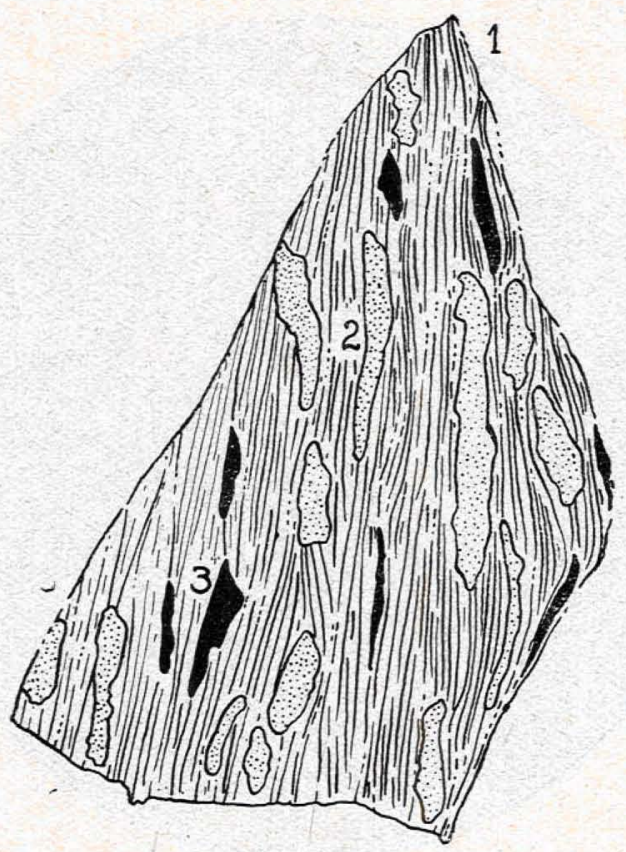

Fig. 8

Desenho de uma amostra macroscópica de minério, mostrando molibdenita (3) e calconirita (2) disseminadas em xisto. (1)

de flutuação e um reativo depressor da calcopirita. A concentração do minério de molibdenita é feita em engenhos comuns de mineração, com bateria de flutuação. Em primeiro lugar, o minério sof́re britagem. Passa depois ao moinho de bolas onde é reduzido a pó impalpável; daí segue para as células de flutuação, onde reativos apropriados - para o caso da molibdenita usa-se o qu'erosene - separam o minério do estéril por meio da espuma, a qual é em seguida filtrada, obtendo-se assim o concentrado.

C a l c o p i r it a - Este mineral é encontrado intimamente associado à molibdenita e ao epídoto (fig. 8 e microfoto 8 ). Não ocorrem cristais idiomorfos e perfeitos. Seu xenomorfismo é ainda mais acentuado do que o da molibdenita. Ocorre também disseminada no xisto feldspatizado encaixante em maior escala do que a molibdenita. Altera-se fàcilmente quando exposta ao ar, 
tornando-se iridescente. Por alteração em maior gráo fornece bornita, malaquita e mais raramente azurita.

$\mathrm{M}$ a $\mathrm{g} \mathrm{n}$ e $\mathrm{t}$ i t a - A magnetita apresenta-se, no minério, em cristais octaédricos pequenos $(1 / 2 \mathrm{~mm})$, associados à molibdenita e à calcopirita. Como a calcopirita, a magnetita altera-se com facilidade, ao contrário do que acontece com a molibdenita.

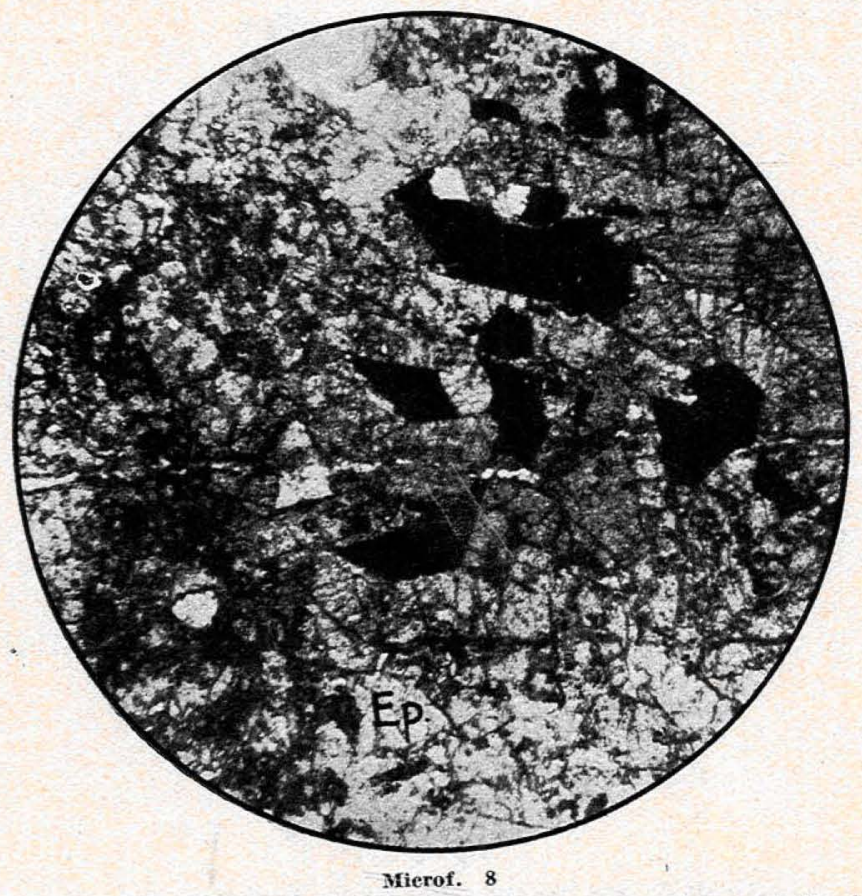

Microfotografia de uma zona do filāo D, nctando-se a associação de calcopirita (opaca) e epídoto (Ep). L.N. $35 \mathrm{X}$.

Consequentemente, observamos na zona de oxidação, minério já alterado, constituido de molibdenita, limonita e malaquita, sendo êstes dois últimos produtos de alteração, respectivamente, de magnetita e calcopirita.

B o r n it a - Foi observada em lâminas interclusas na rocha encaixante. Não foi encontrada nos filões. Fàcilmente alterável, encontrâmo-la raramente fresca. Còr bronze de cobre quando inalterada, tornando-se fortemente iridescente quando alterada superficialmente. Pouco disseminada, não se apresentando em cristais idiomorfos.

P i r i t a - A pirita mostra-se em cristais bem individualizados, de forma cúbica (100), estriados, raramente alterados, estando mergulhados em clorita-xisto ou xisto feldspatizado, em associação com molibdenita. A rocha encaixante que contém pirita, 
freqüentemente apresenta-se alterada, permitindo os cristais se destacarem com facilidade. Provàvelmente, a pirita é aurifera, s'emelhante à pirita de Lavras.

O uro e l e m e n tar - Ouro foi verificado em filões quartziferos, sob a forma de pequenos grãos. Contudo, é freqüente encontrar-se ouro com mineral secundário nos aluviões dos rios.

C o b r e e l'e m e n t a r - Cobre nativo (elementar) foi verificado nas fendas da rocha encaixante, sob forma de dendritos muito friáveis que se desfazem fàcilmente com água, trans-

formando-se em pó. Foi observado escassamente nas regióes mi-
neralizadas.

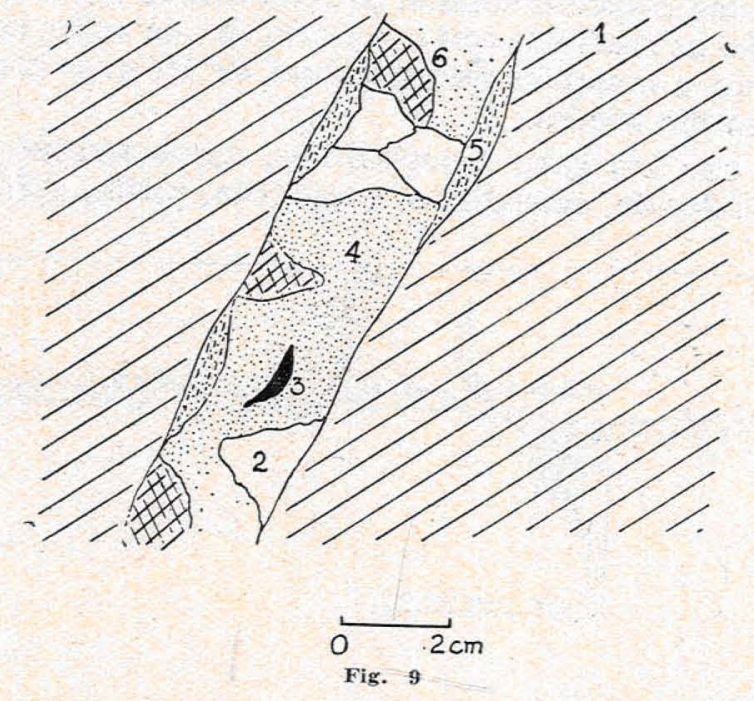

Filão encaixado em xisto feldspatizado, mostrando associação entre molibdenita, fluorita, epidoto, quartzo e calcita,

F l u o r i t a - A fluorita foi verificada em veios na encaixante, em associação com a molibdenita (fig. 9). Os cristais são pequenos, cúbicos, de cêrca de $1 \mathrm{~mm}$, de coloração roxo-clara a incolor e associada à calcita e ao epídoto.

E p i d o t o - Èste mineral, comum em toda a zona de contacto entre xistos e granito forma núcleos e filões homogênios só epídoto - ou heterogênios - plagioclásio e epídoto - no seio do granito ou do xisto feldspatizado. Em pequena quantidade, encontrâmo-lo também nas fendas dos xistos e nos filões quartziferos, localizando-se nestes últimos principalmente nas paredes.

C a l c i t a - A calcita preenche fendas no clorita-xisto encaixante. Apresenta-se em cristais bem formados, de hábito escalenoédrico, nos quais se notam as formas de romboédro e esca- 
lenoédro. Os cristais são de regra, perfeitamente transparentes, ou às vezes, ricos de impurezas de óxido de ferro, que lhes emprestam ligeira coloração parda. Não raramente os cristais apresentam inclusões de películas de óxido de manganês. O tamanho dos cristais é variável, oscilando em torno de $2 \mathrm{~cm}$. O maior cristal observado possuia $5 \mathrm{~cm}$ de altura. Suas faces são perfeitamente planas ou escamosas (estas últimas só foram observadas nos cristais maiores e representam imperfeições de crescimento).

\section{Filões.}

Como foi assinalado na fig. 10 , os filões mineralizados são cinco, designados respectivamente pelas letras $\mathrm{A}, \mathrm{B}, \mathrm{C}, \mathrm{D}$ e E. Os filões A e C são os mais possantes e os únicos de valor econômico, tendo mostrado o comprimento máximo de $15 \mathrm{~m}$ e largura máxima de $20 \mathrm{~cm}$ em média.

Os filões são em geral quartziferos, apresentando mineralização de molibdenita, calcopirita, magnetita, pirita, epídoto, fluo-

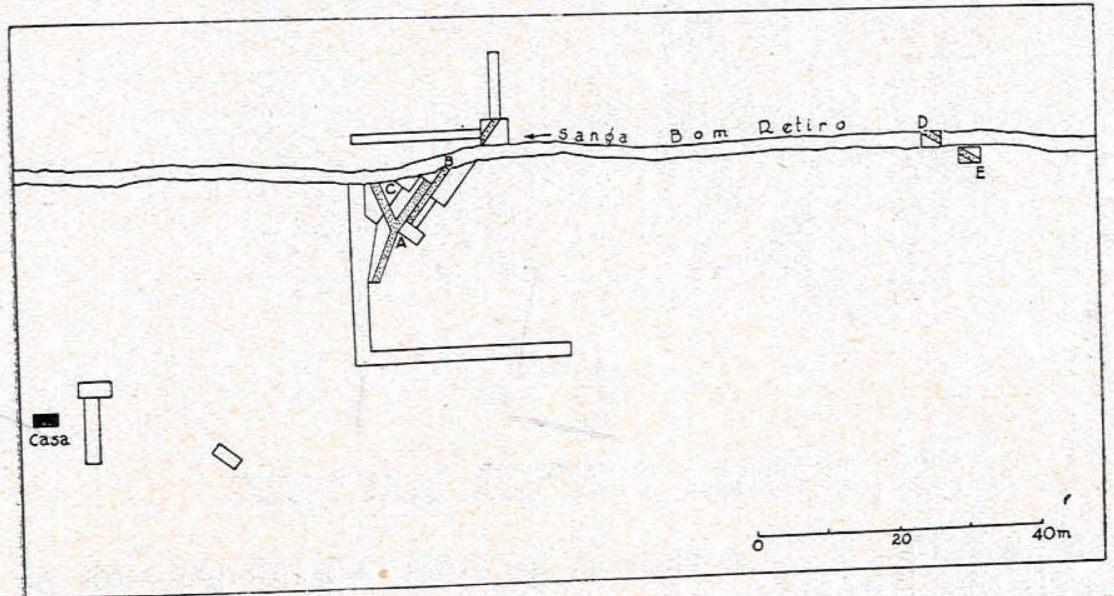

Fig. 10

Esboço da jazida de Vacacaí, mostrando a situação dos filóes A, B, C, D e E.

rita, etc. Êstes minerais ocupam, de modo geral, a periferia dos filões, distribuindo-se, entretanto, ainda entre as fendas e grãos de quartzo. O mineral que ocorre particularmente na periferia é o epídoto.

Apesar dos filóes serem quartzíferos, o quartzo, às vezes, desaparece quase completamente, sendo substituido pelos minerais metálicos. Os filões que mais característicamente apresentam êste aspecto pobre em quartzo são A e C. Os filões B, D e E são predominantemente quartziferos. 
Filão A - (fig. 11) Comprimento: 15m; largura máxima: $20 \mathrm{~cm}$. O quartzo apresenta-se escasso, embora se trate genèticamente de filão quartzífero mineralizado. Ramifica-se em apófises laterais na rocha encaixante. O minério concentra-se em bolsas que seguem a direção do filão, N $45^{\circ} \mathrm{E}$ e N $25^{\circ} \mathrm{E}$, em concordância com os planos de xistosidade dos têrmos metamórficos. A bolsa de maior volume observada, apresentava $1 \mathrm{~m}$ de comprimento por $20 \mathrm{~cm}$ de espessura.

Os minerais em maior freqüência neste filão são molibdenita e calcopirita, em menor, a magnetita. Rocha encaixante: micaclorita-xisto f'eldspatizado em pequena escala.

Filão C - - (fig. 11) - Não foi observado aquí guia filão de quartzo. Os minerais que ocorrem neste filão são os seguintes: molibdenita, pirita, e calcopirita, sendo esta última presente em pequena escala ou mesmo ausente. Direção: N $35^{\circ} \mathrm{W}$; inclinação: $80^{\circ}$ S. Encaixado pelo mesmo tipo de rocha que o filão anteriormente descrito.

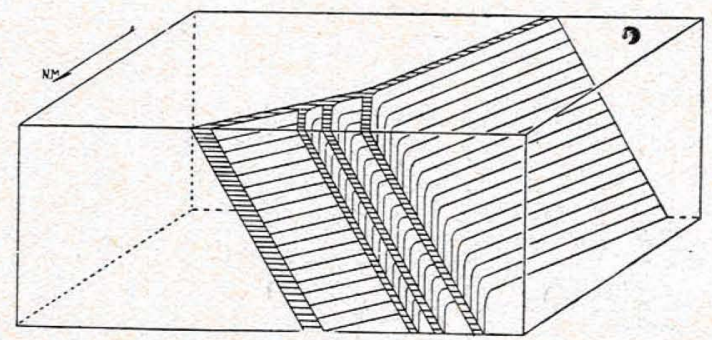

Fig. 11

Bloco-diagrama do filão A e suas ramificações. Neste desenho estão esquematizadas apenas as direçōes e as inclinações dos filões, mas não as suas formas. $\mathrm{Na}$ realidade, êles possuem paredes onduladas (fi:б̆es em

Filão $\mathrm{B}-\mathrm{E}$ ' semelhante ao filão $\mathrm{A}$, mostrando-se porém mais rico em quartzo. Apresenta a mesma direção e inclinação que o filão A. Comprimento verificado: $10 \mathrm{~m}$; largura máxima: $20 \mathrm{~cm}$. Provàvelmente é o mesmo filão que foi descoberto em 8 . Rocha encaixante: mica-clorita-xisto feldspatizado em pequena escala.

Filões E e D - (fig. 12) — Êstes dois filões são idênticos entre si quanto aos característicos mineralógicos, diferindo apenas quanto ao volume. Ambos são filões predominantemente quartziferos, com segregação paragenética de molibdenita e calcopirita como minerais metálicos e epídoto como mineral não metálico. Éste último ocupa, de preferência, as paredes dos filões. A rocha encaixante é constituida por xisto feldspatizado e sericitizado (microfotos 9 e 10). As dimensões dos filões são: filão $D$ : compri- 
mento $5 \mathrm{~m}$ x largura máxima de $5 \mathrm{~cm}$; filão $\mathrm{E}$ : comprimento $3 \mathrm{~m} \mathrm{x}$ largura máxima de $5 \overline{c m}$.
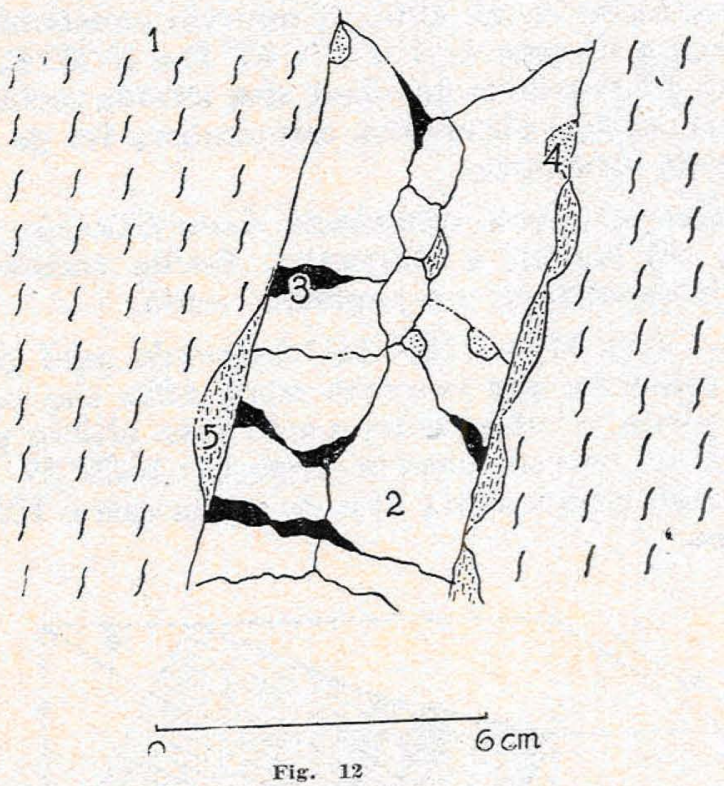

Fig. 12

Esquema dcs filóes $E$ e $D$

1 - xisto feldspatzado encaixante.

2 - quartzo.

3 - molibdenita.

4 - calcopirita.

5.- - epidoto.

3. Rochas encaixantes.

De duas espécies diferentes são as rochas encaixantes: 1 clorita-xisto acentuadamente silicificado, sericitizado e parcialmente feldspatizado, encaixante dos filóes $\mathrm{D}$ e $\mathrm{E}$ (microfotos 9 e 10) ; 2 - mica-clorita-xisto com maior quantidade de talco, passando às vezes a talco-xisto, como silicificação e feldspatização incipientes. A rigor, podemos considerar, no entanto, estas duas rochas como graus diferentes de maior ou menor ação metamórfica de contacto. Assim, no primeiro tipo, o metamorfismo se fez sentir mais intenso, evidenciado pela sericitização e silicificação mais pronunciadas; no segundo, menos.

Primeiro tipo - (microfotos 9 e 10 e figs. 13 e 14) - As rochas desta categoria possuem estrutura xistosa e textura granuloblástica passando a porfiroblástica. Notam-se vários cristais de quartzo mais desenvolvidos que os demais das outras espécies. Há, também, cristais pequenos de quartzo. A presença dêste mineral indica, além de outros fenômenos, processo de silicificação 
dos xistos da série Porongos na zona de contacto. Considerando que a silicificação é mais intensa em alguns pontos que em outros, somos levados a supòr silicificação por precipitação de soluções hidrotermais, que teriam ascendido pelos caminhos mais fáceis, formando zonas mais ricas em sílica. O quartzo apresenta extinção ondulante e contôrno alotriomorfo. Seus cristais maiores, assim como os pequenos agrupamentos, podem ser considerados filões incipientes.

Juntamente com a silicificação, houve um processo intenso de sericitização. Tudo nos leva a crêr que os xistos tenham sido feldspatizados por metamorfismo de injeção "lit-par-lit" e após êste processo, os feldspatos, principalmente o ortoclásio, sofreram sericitização por ação hidrotermal, dada a pequena abundância de feldspato e riqueza relativa de sericita observada. Como sabemos, a sericita revela em sua análise química um acréscimo maior em sílica do que a variedade muscovita (36), e por esta razão aquele mineral só teria origem, onde fossem mais altas as condicões de silicificação. E' èste fato que realmente observamos em tal rocha encaixante. A riqueza em quartzo e sericita demonstra que a so-

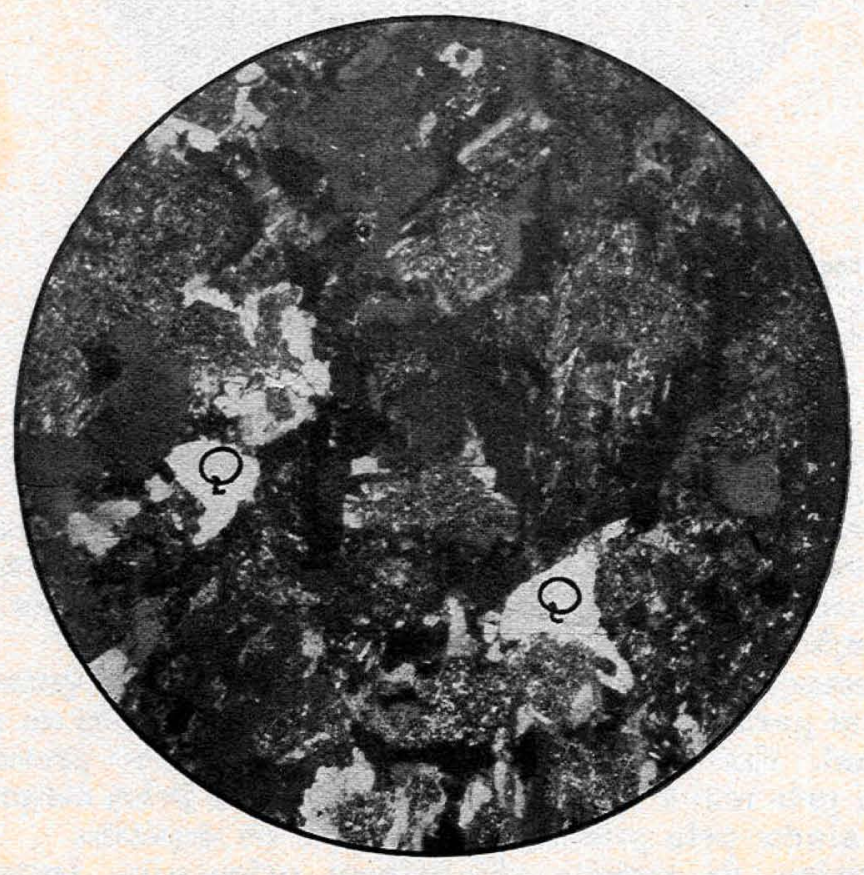

Mierof. 9

Xisto feldspatizado encaixante, notando-se quartzo (Q), albita sericitizada. e sericita. Encaixante dos filöes D e E. N $\mathrm{N}+35 \mathrm{X}$. 
lução residuária deveria ter sido rica em sílica e potássio (solucão alcalina). Não existe ortoclásio na rocha encaixante, embora ểle exista em relativa abundância no granito intrusivo, visto que $o$ ortoclásio ter-se-ia transformado totalmente em sericita. $\mathrm{O}$ pla-

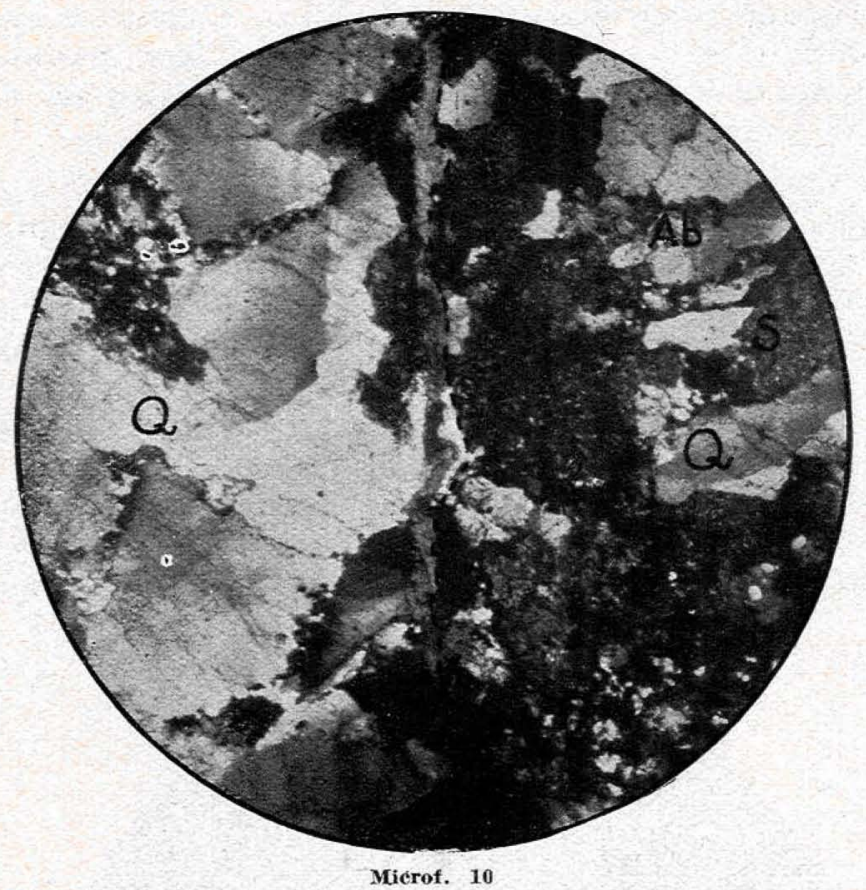

Filão em contacto com a encaixante - A encaixante é um xisto feldspatizado e sericitizado, constituido de quartzo (Q), albita (Ab) e ser.cita (S) principalmente. O filão é quartzifero, notando-se que é formado na sua maioria por quartzo. Êste filão contêm molibdenita e calcopirita, que não são observadas na microfotografia. $\mathrm{N}+35 \mathrm{X}$.

gioclásio, por sua vez, ter-se-ia alterado parcialmente por ser pobre em potássio. Tal fato explica por que se encontram ainda cristais remanescentes de plagioclásio.

A clorita, presente neste tipo de encaixante, poderia ser considerada como originária dos xistos da série Porongos e ter-se-ia também transformado em sericita, remanescendo apenas em pequena porção.

A presença de apatita no interior dos cristais de quartzo nos dá margem para admitir a presença de flúor ou cloro na solução hidrotermal. Entretanto, tudo nos leva a crer na presença de flúor, seja pela maior afinidade dêste elemento pelos magmas ácidos, seja ainda, pela presença de fluorita no depósito.

Os cristais de sericita não exibem orientação, fazendo-nos pensar que talvez não sejam provenientes de clorita, quando então deveriam orientar-se do mesmo modo que esta última. Entre- 


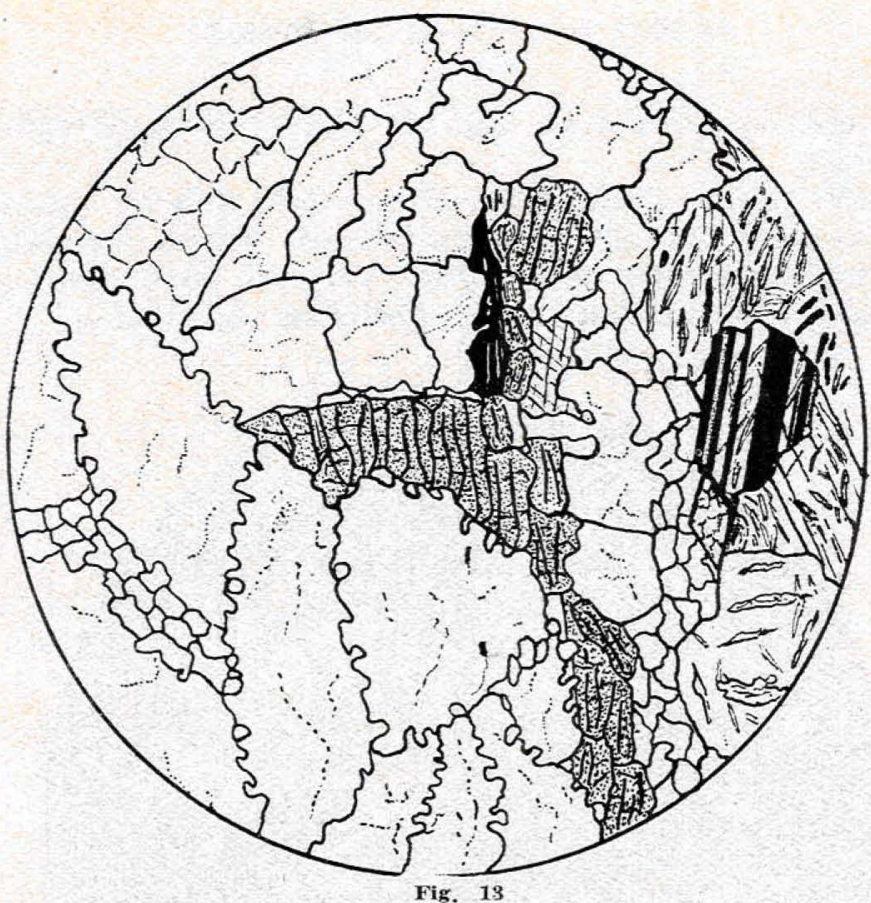

Desenho de uma secção delgada, mostrando o contato entre filāo e encaixante, notando-se muito quartzo no filāo, epidoto no contato (cinzento com traços de clivagem), molibdenita, plagioclásio com sericitização incipiente e sericita na encaixante.

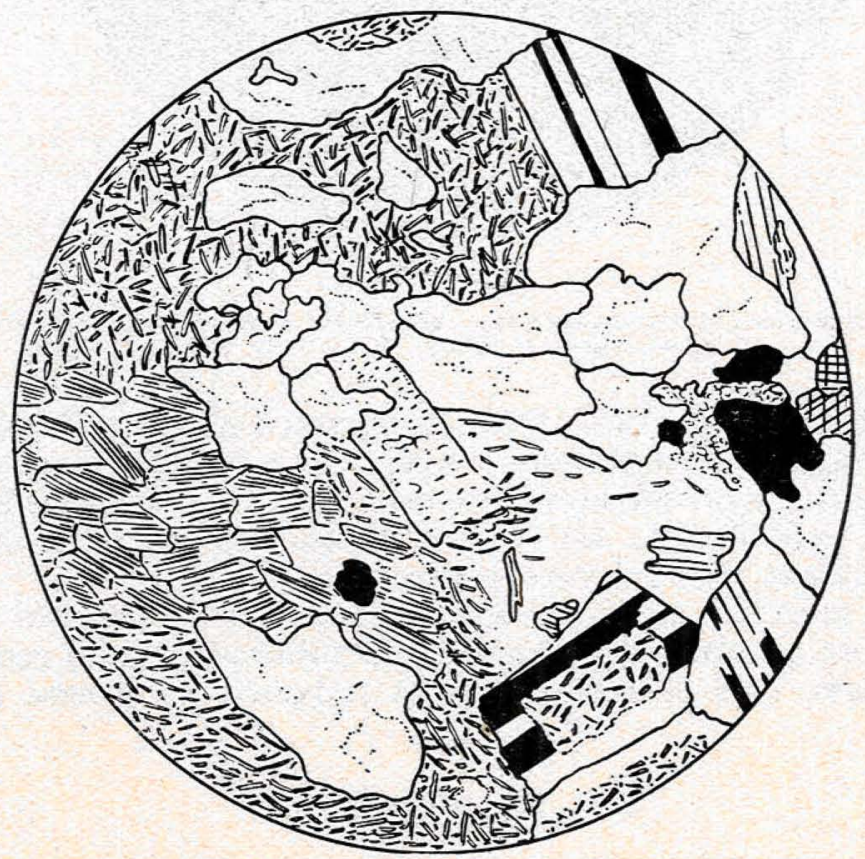

Fig. 14:

Desenho de uma secção delgad - de encaixante dos filóes E e D (primeirn tipo), mostrando clorita (traços de ciivagem paralelos), sericita (cristais peniformes), quartzo, plagioclásio sericitizado, epidoto e impregnaçōes de calcopirita (cpaca). 
tanto, foi notado sericita ao lado de clorita, denunciando possível derivação.

Segundo tipo - (microfoto 11) - Èste tipo de rocha é um mica-clorita-xisto parcialmente epidotizado e com incipiente silicificação local. O epidoto foi observado em núcleos no seio da rocha, fato que demonstra origem posterior secundária.

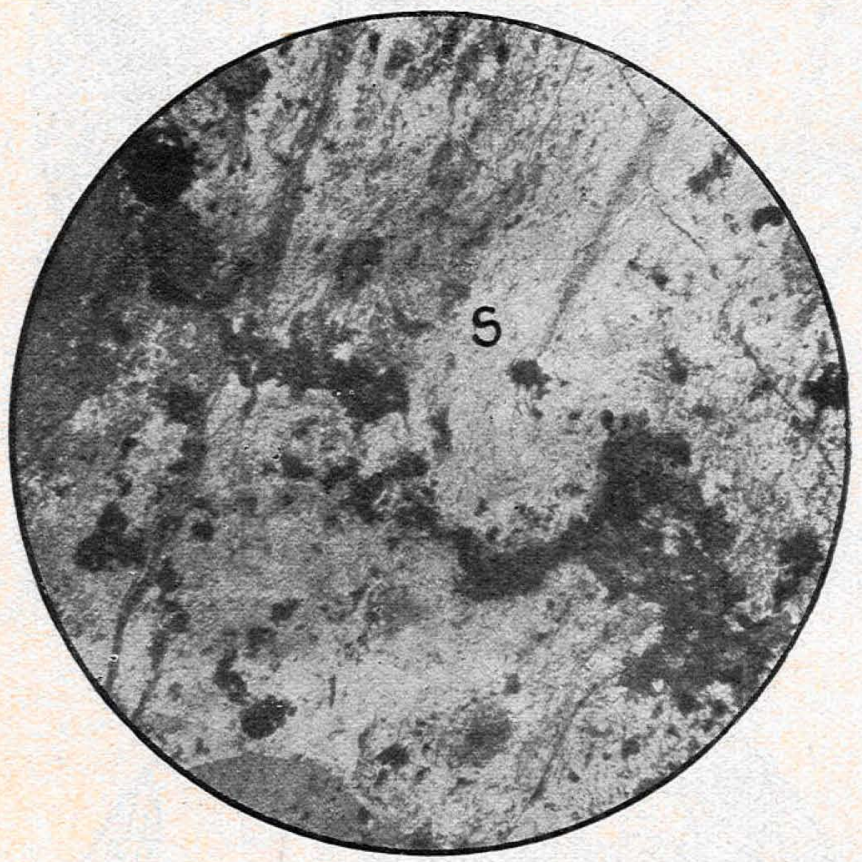

Mierof. 11

Mica-clorita-xisto encaixante com impregnações de calcopirita e molibdenita (opacas) e epidoto (Ep). L. N. 35 X.

A textura é granuloblástica e a estrutura xistosa. Os minerais são em ordem decrescente das respectivas porcentagens: sericita, clorita, quartzo e acessòriamente, sob forma de disseminacões, calcopirita e molibdenita. Os cristais de quartzo são primários na maioria; outros, provàvelmente secundários.

Como teremos ocasião de estudar adiante, no capítulo da mineralogênese, a composicão química ou mineralógica da rocha encaixante teve uma influência muito reduzida na gênese do depósito.

\section{V - Mineralogênese}

1 - Problema da gênese. 


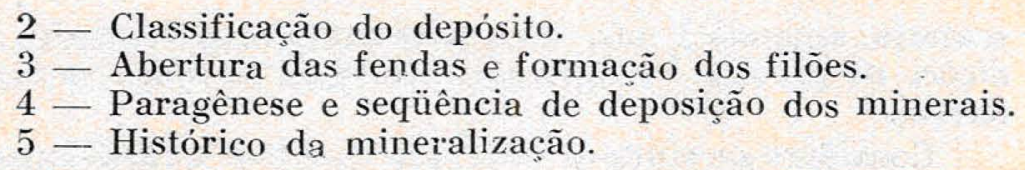

1. Problema da gênese.

No presente estudo teremos como finalidade primordial, sempre que possível, atingir interpretações genéticas. Entretanto, não pensamos obter resultádos indubitáveis e absolutos, pois que os processos naturais são, muitas vezes, convergentes: causas diferentes podem produzir efeitos semelhantes.

Examinando a feição geológica da região da jazida de molibdenita, verificámos a existência de dois afloramentos de rochas magmáticas: um de granito, outro de andesito. São duas formacões que denunciam atividade magmática na região em períodos geológicos diferentes: uma fase intrusiva mais intensa, ocorrida no algonquiano e outra extrusiva ou intrusiva superficial menos intensa, no paleozóico superior. Pelos argumentos apresentados neste trabalho, na parte referente à geologia propriamente dita (pg. 34 e ss.), verificámos que o granito é anterior ao andesito (superposição ao granito e presença de núcleos graníticos epidotizados dentro da massa de andesito). E' de se supor que ambos os magmas produziram efeitos de metamorfismo de contacto e post-eruptivo nas rochas da região: o magma granítico em maior escala por ser intrusivo e o andesítico em menor por ser extrusivo. Tal fato nos leva a acreditar em duas possibilidades sôbre a origem do depósito de molibdenita de Vacacaí, ambas entretanto, hidromagmatógenas: possibilidade de formação post-andesítica (solução residuária andesítica) e possibilidade de formação post-granítica (solução residuária granítica). Entretanto, como ainda teremos ocasião de ver, somos de parecer que a segunda possibilidade seja a mais viável.

Formação post-andesítica - A vizinhança de afloramentos andesíticos permite-nos sugerir uma origem de depósito de molibdenita, por atividade magmática andesítica. Em abono desta hipótese considere-se o fato, de que o mineral em maior porcentagem é calcopirita e não molibdenita, apesar da jazida ser chamada de molibdenita por motivo econòmico e, como é sabido, a calcopirita é de gênese relacionada com magmas intermediários, dentro dos quais se enquadra o magma andesítico. De outro lado, como bem mostra V. Leinz (23) (25) de estudos exaustivos executados nos depósitos de cobre e ouro do Estado do Rio Grande do Sul, as jazidas dêstes metais ou de seus compostos minerais originaram-se, na maioria absoluta, de soluções hidrotermais provenientes de magma andesítico. Assim, o depósito de Vacacai repre- 
sentaria, segundo Leinz, veios post-andesíticos formados sob condiçoes de pressão e temperatura as mais elevadas ou seja, hipotermal.

Considere-se ainda o fato, que os filões quartziferos de Vacacaí são também auríferos e, que os filões com ouro encontrados na região de Lavras, onde se fizeram atuar ambos os magmas, tanto o granítico como o andesítico, foram formados por soluções andesíticas e não graníticas.

Formação post-granítica - Com referência a esta hipótese temos a dizer que a maioria dos fatos observados corroboram-na. Analisaremos os mais importantes. E' fato estabelecido que, via de regra, os depósitos de molibdenita estão genèticamente relacionados com atividade ígnea de magmas ácidos (22), de preferência graníticos e mais raramente sieníticos e granodioríticos, têrmos, no entanto, ainda ácidos da série das rochas magmáticas. Assim. em Climax, Colorado, U.S.A., a molibdenita ocorre disseminada em granito. Butler e Vanderwilt (5) são de opinião que êsse depósito seja do tipo mesotermal. Fuster (10) estudando uma ocorrência de molibdenita na região de Cornwall, Inglaterra, observou êsse mineral em veio de quartzo cortando xisto turmalinífero e em correlação genética com granito. Gerrie (12), na região de Quebec, Canadá, encontrou molibdenita em veios de pegmatito, encaixados em biotita-xisto e nas circunvizinhancas de uma intrusão granítica. Na região de Chekiang, Ming e Chang (30) encontraram molibdenita em veios quartzosos atravessando pórfiro granítico. Brown (4), de estudos em depósitos de Burma, Índia, verificou molibdenita incluida em argilito, xistos e quartzito, relacionada genèticamente com magma granítico. Mario de Jesus (29), de pesquisas sôbre pegmatitos mangano-litiníferos de Mangualde, Beira, Portugal, onde é verificada molibdenita, mostra que tais depósitos se formaram em quatro fases magmatógenas (magmática, hipotermal, hidrotermal fosfática e hidrotermal sulfídica), relacionadas com atividade eruptiva granítica.

Do exposto, vê-se que os exemplos citados de algumas regiões bem diversas da face da terra, constituem jazidas e ocorrências de molibdenita, genèticamente relacionadas com atividade granítica. Outros exemplos poderiam ser citados (17 - ver Hintze), mas seriam tão numerosos e sua enunciação tão longa, que fugiria a finalidade do presente trabalho. Contudo, citaremos ainda alguns outros exemplos de jazidas genèticamente ligadas à atividade eruptiva, mas agora, sienítica e dioritica, embora sejam elas em número mais reduzido do que as primeiras de origem granítica. Assim, Truman (37) de pesquisas executadas nos depósitos de cobre da área de Creek, Arizona, U.S.A., onde também ocorre molibdenita, concluiu que tais depósitos se formaram em consequência de intrusão granodiorítica em sedimentos cretíceos. $\mathrm{E}^{\prime}$ inte- 
ressante notar que, nesta jazida, a molibdenita foi o último mineral hipógeno a se depositar, ao passo que nas demais jazidas é, em geral, dos de mais precoce separação, como se pode depreender da paragênese, que é a seguinte: pirita, calcopirita, bornita, tenantita, esfalerita, galena e molibdenita. No Japão, Susuki (37), investigando depósitos de metamorfismo de contacto da região de Ofuku, demonstra que uma intrusão diorítica foi responsável pelo metamorfismo de arenitos, xistos e calcáreos paleozóicos, produzindo uma zona de contacto com minerais característicos e formação de um depósito hidrotermal com a seguinte paragênese: calcopirita, pirita, mispiquel, molibdenita, blenda, galena e scheelita. Zambonini $(40)$, dos estudos quimicos realizados em lavas traquíticas do Vesúvio, encontrou os seguintes elementos entre os quais figura o molibdênio: Mo, Br, Ta, I, V, W, Se, Te, As, Nb, Ti e terras raras. Gilluly (11), de pesquisas em depósitos minerais de Arizona, U.S.A., verifica que a mineralização de molibdenita e outros minerais da região de Ajo, se deu em virtude da ação de um magma monzonítico.

No Brasil, a molibdenita também tem sido sempre encontrada em relação genética com granito. Confirmando èste fato, encontramos em Porto Alegre e em Lavras, molibdenita como mineral acessório no granito. Em Encruzilhada, R. R. Franco (9) verificou molibdenita em veios quartziferos, originados de soluções hidrotermais de magmas graníticos.

Na região de Vacacaí foram verificadas várias ocorrências de molibdenita dentro da zona de contacto do granito com o xisto, e encaixadas portanto pela rocha de contacto, xisto feldspatizado (ver mapa). Entretanto, não foram observadas ocorrências dentro da zona de contacto com o andesito. Como veremos adiante, o nosso depósito se formou sob condições de elevado p.t., o que não acontece em geral, com magmas extrusivos ou intrusivos superficiais, os quais raramente fornecem soluções hidrotermais de alta temperatura e pressão. Ainda as soluções derivadas dos magmas extrusivos ou intrusivos superficiais são de regra epitermais ou mesotermais.

A molibdenita e seus minerais de associacão ocorrem em Vacacaí sob a forma de veios e filóes de composição ricamente quartzosa. Considerando-se êste fato, verossimilmente êles se originaram do magma granítico.

A sericitização indica presença de metais alcalinos, principalmente potássio, nas soluções residuárias. Como diz Graton (14), a maioria dos depósitos minerais é formada por soluções alcalinas, por serem estas as soluções com maior capacidade de dissolução, e portanto carregando maior quantidade de substâncias dissolvidas, são por conseguinte, mais mineralizadoras. 
O molibdênio, como os demais elementos constituintes da crosta terrestre, está nela disseminado em pequena porcentagem. No entanto, é de se supor que concentre preferentemente nas rochas ácidas, pelas observações até hoje obtidas. Com referência a êste fato comparem-se os resultados de detecção de molibdènio em rochas básicas e ácidas realizados por diversos autores. Verificou-se que o teôr em Mo apresentado pelas rochas básicas é menor em relação à média das observações. Assim, Vernadsky $(38$, pg. 21) dá o seguinte teôr aproximado do molibdênio, para até uma profundidade de $20 \mathrm{~km}$ através da crosta, correspondentes a $3,25 \times 10^{19}$ de matéria: $10^{-3}$ a $10^{-2} \%$ de Mo, o que significa $10^{14}$ a $10^{15}$ toneladas de molibdênio para todo o volume da crosta terrestre. Já Koppel e Berg, citados por Krusch $(21$, pg. 4) dão para a porcentagem de molibdênio o seguinte valor: $7,2 \cdot 10^{-6}$. Hevesy e Hobbie (16) em uma mistura de 282 exemplares de rochas eruptivas, encontraram o teôr de $1,5 \cdot 10^{-5} \mathrm{~g} / \mathrm{g}$ de Mo. Os mesmos autores (16) em 67 exemplares de rochas gábricas de diversas procedências encontraram o teôr médio de $0,3 \cdot 10^{-5} \mathrm{Mo} \mathrm{g} / \mathrm{g}$.

Do exposto, notamos que o molibdênio, como os demais elementos, está disseminado na crosta terrestre, concentrando-se porém em magmas ácidos, formando com outros elementos, minerais que são encontrados em jazidas relacionadas com tais magmas.

Hullin, citado por Newhouse (31), admite que a fonte magmática do molibdênio, assim como do estanho e do wolfrâmio é muito ácida.

Finalmente, em abôno da hipótese post-granítica podemos lembrar que o fluoreto de molibdênio, provável forma pela qual ascendeu o molibdênio em Vacacaí, é muito volátil (p.f.: $17^{\circ} \mathrm{C}$ e p.e.: $\left.35^{\circ} \mathrm{C}\right)$. Tal composto, portanto, dificilmente precipitarse-ia a partir de magmas andesíticos, porquanto sendo tais magmas na maioria extrusivos, os compostos de molibdènio desprenderse-iam com facilidade, perdendo-se na atmosfera. Sendo ademais o depósito, hipotermal, convém salientar que tais depósitos de elevado p.t. formam-se exclusivamente a expensas de magmas batolíticos.

Pela maior soma de fatos e observacões a favor da hipótese post-granítica, tais como, exemplos de outras jazidas estrangeiras e brasileiras, pela verificação geoquímica (maior teòr de molibdênio em rochas ácidas), ocorrências de molibdenita na zona de contacto do granito em Vacacai, alcalinidade das soluções originárias, volatilidade dos compostos de molibdênio, só passíveis de se precipitarem em ambiente fechado e, ainda pelo fato da jazida se localizar na zona de contacto do granito, somos levados a admitir que a jazida, apesar de não ter sido observada conexão direta entre granito e filões, formou-se por soluções post-graníticas. 


\section{Classificação do depósito.}

A molibdenita e a calcopirita, principais minerais que ocorrem na jazida de Vacacaí, podem ter o seu climax de precipitação durante qualquer fase da emanação post-eruptiva, porquanto os seus elementos formadores fazem parte dos componentes voláteis (ichor) do magma, principalmente os compostos de molibdênio. Assim, a molibdenita e a calcopirita podem se originar de soluções aquo-ígneas até epitermais, passando pelas fases intermediárias de hipo- e mesotermal. A molibdenita, especialmente, pode se formar em diversos ambientes e sob várias condições de p.t. Assim, encontrâmo-la em pegmatitos em Quebec, Canadá, e em Magnet Cove, Arkansas, U.S.A.; em depósitos de metamorfismo de contacto em Marrocos e em Ontario, U.S.A.; em depósitos de substituição, sob forma disseminada, em Climax, Colorado, U.S.A. e em Cananéa, Mexico, ou ainda em veios hidrotermais como em Questa, Novo Mexico, U.S.A. e em Copper Creek, Arizona, U.S.A. (3, pg. 592).

Vimos, pela descrição da jazida e dos minerais que a constituem (pg. 48 e ss.), que não há ocorrência de feldspato e tampouco de mica nos filões estudados, fato êste que denunciaria formação pegmatítica ou hipotermal profunda. Observamos ainda que os filões possuem estrutura em rosário e, que há sericitização na encaixante, fatos que vêm eliminar a possibilidade de classificarmos o depósito como epitermal, quando então não haveria uma substituição tão pronunciada na rocha encaixante. A abundância de quartzo na maioria dos filões, como ganga quase exclusiva, da mesma maneira vem falar a favor da origem hidrotermal em condições de temperatura e pressão elevadas. De outro lado, a maior porcentagem de quartzo em relação a de sericita, leva-nos a admitir a formação dos filóes e as modificações das rochas encaixantes, como ocorridas em níveis mais altos, porquanto a sericita aumenta com a profundidade e é relativamente escassa nas regiões pouco profundas (36). Ėste fato nos induz a pensar em formação a p.t. menos elevado. No entanto, como já tivemos ocasião de verificar anteriormente, que foi encontrada pirita e não marcassita, como modificação do bisulfêto de ferro, è é fato bem conhecido em mineralogia, que a pirita é produto de filões profundos e de fontes quentes, ao passo que a marcassita, em geral, se forma próxima à superfície, por soluções frias ou menos quentes. Do mesmo modo, se tivessemos veios de p.t. menos elevado, deveriamos ter encontrado, além de quartzo como ganga, outros minerais tais como baritina, etc.

A textura do minério, como se pode depreender da fig. 7 , não exibə ânogulos, fato êste comum nos minérios epitermais.

Por estas várias razões, composição mineralógica e configuração geológica da jazida, e também pela estrutura fitada dos filões 
denunciando ascensões sucessivas de soluções residuárias e que portanto o periodo de formação foi longo e perdurou sob diversas condições de p.t., somos levados a crêr que o depósito de Vacacaí, seja do tipo hipomesotermal, de acôrdo com a classificação dos depósitos minerais de Lindgren (28).

Em abòno desta idéia, convém mencionar que quando o depósito é de formação de baixo p.t., a molibdenita aparece em escala microscópica, acontecendo o contrário quando o filão é de alto p.t. Como em Vacacaí, a molibdenita ocorre em relativa abundância e concentração, confirma a sua origem sob elevado p.t.

3. Abertura das fendas e formação dos filões.

Examinando o aspecto geológico apresentado pela região por nós estudada, verificámos que a zona de contacto é bem extensa e o número dos filões, sejam mineralizados ou não, é reduzido em relação à extensão do contacto. Ora, sendo a zona de contacto tão extensa, a probabilidade de se encontrarem filões também deveria ser grande, proporcionalmente. No entanto, tal não se verifica, seja porque os caminhos de acesso às soluçôes deveriam ter sido em número bem pequeno, seja porque, ter-se-iam formado numerosos filões, posteriormente destruidos pela 'erosão. Somos de opinião que os dois fatores devam ter influido.

Os filões estudados tiveram, indubitávelmente, a sua formação facilitada por uma falha, cujo espelho de escorregamento foi notado nas paredes dos filões. As soluções residuárias, encontrando menor resistência na altura da falha, teriam ascendido, originando os filões. Acreditamos na existência de uma falha, mas não de uma abertura preexistente. Provàvelmente, essa zona de menor resistência foi aberta, não sòmente pela pressão das soluções ascendentes contra as paredes da encaixante, como também pela pressão de cristalizacão dos minerais que se formaram e pela ação química mineralizadora das soluções. Dêste modo, teriam sido substituidas as paredes da encaixante, formando-se filóes em rosário, de paredes onduladas e irregulares, mostrando típico processo de reabsorção e reprecipitação. As soluções não se precipitaram exclusivamente na fenda aberta pela pressão e corrosão, mas penetraram ainda nas pequenas fendas xistosas da encaixante em extensão de mais ou menos $20 \mathrm{~cm}$, de lado a lado, impregnando-as de molibdenita e calcopirita sob forma de disseminações laterais. Na fenda principal, precipitou-se quartzo, libertando os componentes voláteis, que se precipitaram tanto no próprio filão, entre grânulos de quartzo, como também entre o filão e a encaixante. Formaram assim as salbandas e as disseminações laterais no interior da própria encaixante. 
O molibdênio, possivelmente, ascendeu sob forma de fluoreto, não só por ser êste componente mais comum em magmas ácidos, mas também pela presença de fluorita na jazida. Posteriormente, quando as condições de p.t. nos filões permitiram a precipitação do quartzo, o fluoreto de molibdênio se libertou, reagiu com outros componentes, como $\mathrm{H}_{2} \mathrm{~S}$, formando $\mathrm{MoS}_{2}$. Pela composição mineralógica do filão, podemos dizer que a solução residuária geradora deveria ter sido rica em sílica e água, componentes comuns dessas soluções, de enxofre ou seus compostos (riqueza em sulfêtos dos filõ'es) e fluorêto de molibdènio (presença de molibdenita e fluorita). A propósito, lembramos que na maioria das jazidas de molibdenita, é comum encontrarmos também em associação com êste mineral, fluorita.

\section{Formaçâo da molibdenita (provável)}

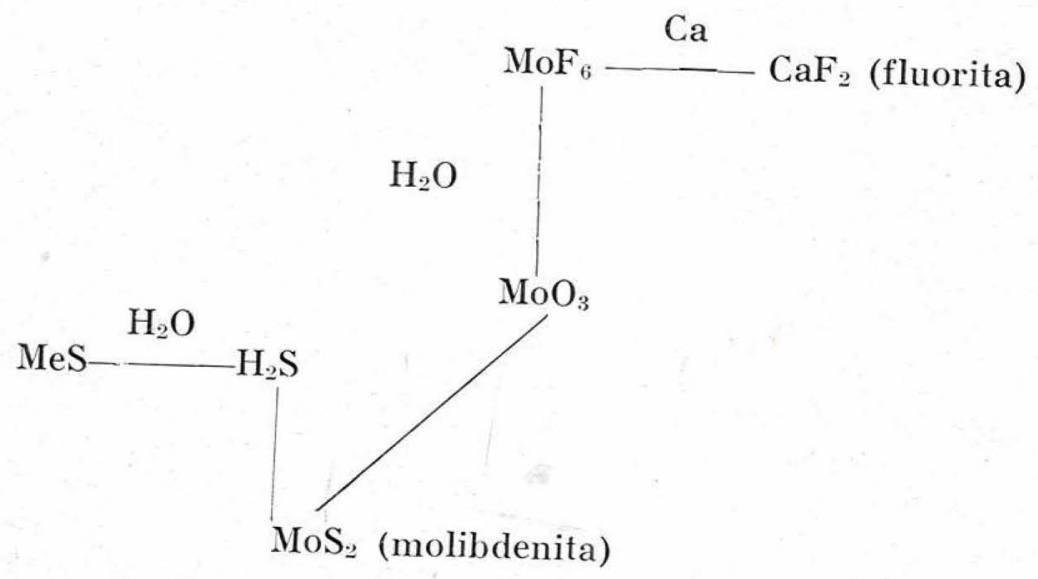

Possivelmente, o flúor reagiu com a p'equena quantidade de cálcio da encaixante, resultando conseqüentemente pequena quantidade de fluorita. O flúor restante provàvelmente foi perdido, ou, como volátil que é, tenha ido reagir em alturas mais elevadas, hoje completamente destruidas pela erosão.

No entanto, o molibdênio poderia ter ascendido sob a forma elementar, transformando-se sob ação da água em $\mathrm{MoO}_{2}$, e êste sob influência de $\mathrm{H}_{2} \mathrm{~S}$, formado $\mathrm{MoS}_{2}$, tal como na obtenção artificial da molibdenita (13).

Os filões não se originaram exclusivamente na fenda da falha verificada, se bem que sejam êstes os filões mais ricos em molibdenita e os outros minerais de paragènese, como também se formaram na direção das diáclases principais dos xistos encaixantes. Como se poderia prever, dada a pequena continuidade das fendas 
diaclásicas, os filões aquí formados são pequenos em extensão e largura, como também em mineralizacão. E' curioso notar qu'e as paredes dêsses filões não são corroidas 'e mostram-se quase paralelas. E' possivel que êste fato seja devido não ao baixo p.t. das soluções, como se poderia pensar à primeira vista, mas sim devido a grande estabilidade dos minerais da encaixante, xisto ricamente feldspatizado, quase um granito, pouco suscetiveis de alteração portanto. Por outro lado, ao microscópio, nota-se intensa sericitização do feldspato da encaixante, na proximidade do filão, indicando substituição pela solução residuária (confirmação da formação hipo-mesotermal).

Não foram verificados na região pegmatitos mineralizados ou não. E' possivel, que futuramente sejam encontrados, dada a extensão do batolito granítico. No entanto, é possível que as condições não tivessem favorecido a formação de pegmatitos, mas apenas de veios hidrotermais.

4. Paragênese e sequência de deposição dos minerais.

No estudo que a seguir faremos sôbre a paragênese dos minerais de depósito de Vacacaí, vamos considerar os minerais de formação hipógena, como também os minerais de formação supérgena, assim como a sequência de separação dos mesmos minerais, esquematizada em diagrama paragenético.

Os minerais observados na jazida, assim como na fonte que lhe deu origem, o granito, foram os seguintes: quartzo, ortoclásio, microclínio, oligoclásio-albita, biotita, pirita, apatita, calcopirita, sericita, clorita, molibdenita, magnetita, bornita, cobre elementar, ouro elementar, epídoto, fluorita, calcita, malaquita, azurita e limonita.

Os minerais hipógenos são: quartzo, ortoclásio, microclínio, oligoclásio-albita, biotita, apatita, calcopirita, sericita, clorita, molibdenita, magnetita, ouro, bornita, epidoto, e fluorita. Os supérgenos são: bornita, cobre, calcita, azurita, malaquita, e limonita. Êstes se originaram por alteraçãe e transformação dos hipógenos. No presente trabalho nos interessa mais de perto a origem e paragênese dêstes últimos. Os minerais hipógenos formaram-se em três fases relacionadas com a atividade magmática granítica: fase magmática, fase de metamorfismo de contacto e fase hidrotermal.

$\mathrm{Na}$ fase magmática formaram-se os minerais que encontramos constituindo o granito e que são os seguintes: quartzo, ortoclásio, biotita, concrescimentos pertíticos e pegmatíticos e apatita. São minerais que se formam na câmara magmática por cristalização direta do magma. Na fase hidrotermal formaram-se os seguintes minerais: quartzo, pirita, apatita, calcopirita, molibdenita, magnetita, bornita, ouro e fluorita. São minerais que se formam 
preferentemente em veios, podendo ser encontrados também como impregnações na rocha encaixante ou na matriz, como acontece com a sericita, calcopirita e molibdenita, que foram encontradas disseminadas na rocha encaixante, como também a fluorita, que foi evidenciada como mineral acidental no granito.

Como mineral resultante do metamorfismo de contacto dos xistos da série Porongos, encontramos o epídoto disseminado em toda a orla de contacto do batolito granítico. O epídoto, além de ter se formado por ação metamórfica de contacto, formou-se ainda nos filões, em íntima associação com minerais hidrotermais, como calcopirita e molibdenita (microfoto 7 ).

Assim como o epídoto, observámos também diversos outros minerais que se formaram por dois ou mais processos ou fases de precipitação. Por exemplo, o quartzo, tanto se formou na fase magmática por cristalização dir đuta do magma, como segregou-se também na fase hidrotermal como precipitação da solução residuária. A sericita da mesma forma formou-se na fase hidrotermal e na fase de metamorfismo de contacto.

Dada a disseminação quase constante da calcopirita nas rochas da zona de contacto, somos levados a crer qu'e êste mineral se originou, não só por precipitação das soluções hidrotermais, como acontece nos filões, como também se originou pelo pirometaso-
matismo.

Os minerais de alto p.t. aparecem, em geral, também na rocha encaixante e dèste modo, podemos considerar de alto p.t. os seguintes minerais: calcopirita, molibdenita e epídoto.

A sequência de separação, principalmente na fase hidrotermal, nem sempre é fácil de ser determinada. Varia de jazida para jazida, e em uma mesma jazida ela sofre variaçóes. Um mesmo mineral pode se precipitar no princípio ou no fim do processo genético, sofr'endo recorrência.

Dèste modo para ver como as sequèncias são as mais variadas, podemos citar e comparar exemplos de diversas jazidas conhecidas. Truman (37) estudando os depósitos de cobre de Creek Area, Arizona, U.S.A., e nos quais ocorre também molibdenita, verificou a seguinte sequência de separação: pirita, calcopirita, bornita, calcocita, tenantita, esfalerita, galena e molibdenita. Como vemos, a molibdenita foi o último mineral a se formar. Kelley (19), que estudou depósitos cupriferos, já verifica que a molibdenita é o mineral de formação mais antiga, seguindo-se a êste mineral, pirita, calcopirita, bornita, calcocita, covelita, tenantita, galena, esfalerita, quartzo, etc. Gilluly (11) verifica em outra jazida a seguinte paragênese, em que a molibdenita ocupa na ordem de separação uma posição intermediária: calcopirita, bornita, pirita, molibdenita, esfalerita, hematita e magnetita. Como bem diz Bandy (1) em seu trabalho sôbre a sequência dos minerais hi- 
pógenos, a molibdenita é um dos minerais, que como a hematita, scheelita, bornita, ouro, etc., não é definitivamente localizado no tempo de formação, e pode precipitar-se em muitas fases da formação post-magmática. Se mesmo na fase magmática, onde as condições de p.t. são mais constantes, a sequência de separação ou cristalização nem sempre segu'e um paradigma determinado, na fase hidrotermal essa sequência é ainda mais variável, pelas mudanças contínuas e de maior grau, de pressão, temperatura e concentração que sofrem as soluções residuárias durante a ascensão.

Em traços gerais, a separação nas soluções hidrotermais obedece a seguinte ordem: silicatos, oxidos, sulfêtos, elementos.

Seja dito de passagem, que sòmente pela riqueza em sulfêtos da jazida e relativa pobreza em óxidos (apenas magnetita em pequena porcentagem), como também de silicatos (epidoto), acreditamos que a jazida é de tipo d'e p.t. elevado a médio, ou seja hipo-mesotermal.

Diagrama paragenético

\begin{tabular}{|c|c|c|c|}
\hline \multicolumn{3}{|c|}{ Hipógenos } & \multirow[t]{2}{*}{ Supérgeños } \\
\hline $\begin{array}{l}\text { Magmática } \\
\text { Solução } \\
\text { silicática }\end{array}$ & $\begin{array}{l}\text { Pegmatitica } \\
\text { Solução } \\
\text { áquo-ignea }\end{array}$ & $\begin{array}{l}\text { Hidrotermal } \\
\text { Solução } \\
\text { aquesa }\end{array}$ & \\
\hline $\begin{array}{l}\text { Apatita } \\
\text { Biotita } \\
\text { Oligoclásio } \\
\text { Albita } \\
\text { Microclinio } \\
\text { Ortoclásio } \\
\text { Quartzo }\end{array}$ & $\begin{array}{l}\text { Concrescimento } \\
\text { gráfico (nicro- } \\
\text { foto 1). }\end{array}$ & $\begin{array}{l}\text { Quartzo } \\
\text { Magnetita } \\
\text { Pirita } \\
\text { Molibdenita } \\
\text { Calcopirita } \\
\text { Bornita } \\
\text { Fluorita } \\
\text { Epidoto } \\
\text { Ouro } \\
\text { Sericita }\end{array}$ & $\begin{array}{l}\text { Bornita } \\
\text { Azurita } \\
\text { Malaquita } \\
\text { Limonita } \\
\text { Calcita }\end{array}$ \\
\hline
\end{tabular}

A sequência de separação entretanto, não é tão rígida como está determinada no diagrama paragenético anexo; ela pode sofrer pequenas variações de acôrdo com as mudanças que podem 
sofrer de igual modo as soluções residuárias na ascensão. Vários são os fatores que influ'em na separação dos minerais hidrotermais e na sua sequência, tais como, segundo Graton (14), abaixamento de temperatura, reações químicas com as paredes da encaixante, mudanças de estado, mudanças de pressão, natureza física dos caminhos abertos, etc., fatores êstes que não são constantes e dai as variações que se observam na sequência.

5. Histórico da mineralização.

Resumindo todos os fatos que foram observados, poderemos esboçar aquí o histórico da mineralização da jazida de Vacacaí, que em traços gerais é o seguinte: nitica.

1. Movimentos orogênicos do algonquiano e intrusão gra-

2. Metamorfismo de contacto e de injeção. Formação de xistos feldspatizados e migmatitos. Formação de grande quantidade de epidoto.

3. Consolidação de magma granítico e ascensão de emanações gasosas, que formaram minerais em alturas hoje erodidas (fase pneumatolítica).

4. Ascensão de soluções hidrotermais, formando molibdenita, calcopirita, magnetita, pirita e outros minerais (fase hidrotermal).

5. Fim da precipitação das soluções residuárias. Fase epitermal. Formação de cobre elementar. calcita.

6. Fase supérgena. Formação de malaquita, azurita, bornita,

\section{VI - Conclusões}

As conclusões mais importantes que podem ser tiradas são as seguintes:

1. O depósito de Vacacaí é hipo-mesotermaĩ (composição mineralógica do minério e da ganga, configuração dos filões, sericitização e silicificação da 'encaixante).

2. Econômicamente, a zona de contacto é interessante, e há possibilidades, se bem que reduzidas, de serem encontrados ainda outros filões com molibdenita e associados, dado ao tipo de gênese da jazida estudada.

\section{Summary and conclusions}

In Rio Grande do Sul, Brazil, in the place named Vacacaí, (São Gabriel district), occurs a mineral deposit of molybdenite. The occurrence of this mineral and others of paragenetic origin 
is located somewhat in the contact area between the Algonquian granite and the schists of the same period, (Porongos series).

The main purpose of this paper was the study of the history of the region, the genesis and the paragenesis of the minerals, and some correlated phenomena.

Special attention was given to the geological and petrographical features of the region, whose rocks consist predominantly of epi-meso-metamorphic schists, granite, andesite and relics of Devonian (?) arkoses (Camaquan series). The alkaline granite which is intruded in the schists was responsible for the effects of contact and "lit-par-lit" metamorphism which follows the structure of the schists.

Feldspathization and sericitization are common in the contact zone.

The molybdenite masses are related to few deep-seated high temperature quartz veins which are enclosed in the feldspathizied schists. The ore minerals are molybdenite, chalcopyrite, pyrite, gold, bornite, copper and magnetite. The gangue is mainly quartz; fluorite, epidot, calcite, limonite and malachite occur locally.

The veins, certainly formed at considerable depths, and classified as hipo-mesothermal veins, according to the Lindgren's classification, are connected to the granitic intrusion.

Molybdenite occurs either in veins or disseminated in the country-rock. The writer is of the opinion that the fluorin had played an important part regarding to the precipitation of molybdenite, whick should be present as a volatile constituent -$\mathrm{MoF}_{6}$ - in the granitic magma.

Finally the author concludes that the first mineral to be formed was molybdenite, which was succeeded by others.

\section{VIII -- Bibliografia}

1. Bandy, M. C. - A theory of mineral sequence in hypogene ore deposits - Ec. Geol. (1940), 546 .

2. Barth, T. F. W., Correns, C. W. e Eskola, P. - Die Entstehung der Gesteine - Berlin (1939).

3. Bateman, A. - Economic mineral deposits - New York (1942).

4. Brown, J. C. - A geographical classification of the mineral deposits of Burma - Rec. Geol. Survey India, 56, 65-108. (1924). Resumo em Mineral. Mag., 21, 279, (1926).

5. Builer, B. S. e Vanderwilt, S. W. - Climax molybdenum deposit U. S. Geol. Surv. Bull. 846C, 233, (1931).

6. Camargo, W. G. R. - Morfologia da wulfenita de Itapirapuan, S. P : : Bol. Mineralogia 7, São Paulo, (1945).

7. Carvalho, P. F. - Reconhecimento geologico do Rio Grande do SuI : Serv. Geol. e Mineral. do Brasil, Bol. 66, Rio de Janeiro. 
8. De Launay, L. _ Gîtes minéraux et métallifères : Librairie Polytechnique Ch. Béranger, Editeur; Paris et Liege, v. 1, (1913), 788.

9. Franco, R. R. - A faixa estanifera do Rio Grande do Sul : Bol. Mineralogia 6, São Paulo, (1944).

10. Fuster, C. N. - On some new mineral localities in Cornwall and Devon : Mineral. Mag. 1, 74 e ss., (1876-77).

11. Gilluly, J. - Geology and ore deposits of Ajo quadrangle, Arizona : Bur. Mines Geol. Sur., 1't1, 79-80, (1937).

12. Gerrie, W. Molybdenite in La Corne and Malartic Townships, Quebec : Univ. Toronto Studies, Geol. Surv., 24, 37-40, (1926). 13. Gmelins Handbuch der Anorganischen Chemie, Molybdan : Berlin, v.
$53,(1935), 182$.

14. Graton, L. C. - Nature of ore-forming fluids : Ec. Geol., 35, (1940).

15. Guimarães, D. - Wolframita e cassiterita, municipio de Encruzilhada : Ser. Geol. e Min. do Brasil, Bol. 21, 64, (1926).

16. Hevesy, G. v. e Hobbie, R. - Die Ermittlung des Molybdan und Wolframgehaltes von Gesteinen: Zeits. Anorg. Ch., 212, 134-144, (1933). Resumo em Min. Mag.

17. Hintze, C. - Handbuch der Mineralogie : Leipzig (1904), Band I,

18. Johannsen, A. - A descriptive petrography of the igneous rocks : Chicago (1932).

19. Kelley, V. C. - Paragenesis of Colorado copper sulphides, Cananéa, Mexico : Ec. Geol. (1935), 663 e ss.

20. Kordes, E. - Die Beziehungen zwischen den Dissoziationdampfdrucken von Sulfiden und ihren Ausscheindungfolge auf magmatoge nen Erzlagerstätten : Min. i. Pet. Mitt., 46, 256 e ss.,
(1935).

21. Krusch, P. - Die Metallischen Rohstoffe, Molybdän, 2 Heft, Stuttgart,

22. Landes, K. K. - Pegmatites and hydrothermal veins $-\Lambda \mathrm{m}$ : Min.,

23. Leinz, V. e Almeida, S. C. Gênese da jazida de colre de Camaquam : Dir. Prod. Min., Bol. 88, Porto Alegre, (19.41).

24. Leinz, V., Barbosa, A. F. e Teixeira, E A. - Mapa geologico Caçapava-Lavras : Dir. Prod. Min., Bol. 90, Porto Alegre,
(1941).

25. Leinz, V. e Teixeira, E. A. - Ouro no Bloco do Butiá : D.N.P.M. Bol. 50, Rio de Janeiro, (1942).

26. Leinz, V. - Calcáreo de Vacacai : Min. e Met. 7, n. 37, 29, Riu

27. Leitmeier, H. e Feigl, F. - Einfache Verfahren zum Nachweis von Molybdän, Blei und Kobalt in Mineralien und Gesteinen : Min. und Petr. Mitt., 47, 313, Leipzig (1936).

28. Lindgren, W. - Mineral deposits : McGraw Hill, New York (1933).

29. Mario de Jesus, A. - Pegmatitos mangano-litiniferos da região de Mangualde : Comun. do Serv. Geol. de Portugal, 19, 65-210, (1933). Resumo em Min. Mag.

30. Ming, H. M. e Chang, K. - On the molybdenite quartz veins of Shinping-Chuan Tsingten, Chekiang : Contrib. Nat. Research Inst. Geol. Sinica, Nanking, 4, 47-58, (1933). Resumo em Min. Mag., 23, 432. (1933-34). 
31. Newhouse, W. H. - The source of vanadium, molybdenum, tungsten and chromium in oxidized lead deposits : Am. Min., 19, 209, (1934) .

32. Oliveira, A. I. e Leonardos, O. H. - Geologia do Brasil : Ministério da Agricultura, Rio de Janeiro, (1943).

33. Rabello, C. Q. - Molibdênio no Brasil : Min. e Met., v. 2, 190, (1942).

34. Roush, G. A. - Strategic mineral supplies : New York.

35. Staples, L. W. e Cook, C. W. - A microscopic investigation of molybdenite ore from Climax, Colorado : Am. Min., 16, (1931).

36. Suzuki, S. - The contact metamorphic ore deposits in the environs of the Ofuku mine, province of Nagato, Japan : Journ. Fac. Sci. Hokkaido Univ. Ser., 2, 69-131, (1932). Resumo em Min. Mag.

37. Truman, H. K. - Pipe deposits of the copper Creek Area, Arizona : Ec. Geol., (1943), 512.

38. Vernadsky, W. J. - Geochemie : Leipzig, (1930).

39. White, D. E. - The molybdenite deposits of the rencontre East Area, Newfoundland : Ec. Geol., (1940), 967.

40. Zambonini, F. - Le richerche chimiche sui materiali della zona vulcanica della Campania nell'Istituto di Chimica Generale della R. Universitá di Napoli negli anni 1923-1929 : Boll. Soc. Geol. Italiana, 49, 179-264, (1931). 
